San Jose State University

SJSU ScholarWorks

Master's Theses

Master's Theses and Graduate Research

Fall 2015

\title{
Effects of small-scale substrate complexity and heterogeneity on rocky intertidal species interactions
}

Sara E. Worden

San Jose State University

Follow this and additional works at: https://scholarworks.sjsu.edu/etd_theses

\section{Recommended Citation}

Worden, Sara E., "Effects of small-scale substrate complexity and heterogeneity on rocky intertidal species interactions" (2015). Master's Theses. 4674.

DOI: https://doi.org/10.31979/etd.39hp-z9et

https://scholarworks.sjsu.edu/etd_theses/4674

This Thesis is brought to you for free and open access by the Master's Theses and Graduate Research at SJSU ScholarWorks. It has been accepted for inclusion in Master's Theses by an authorized administrator of SJSU ScholarWorks. For more information, please contact scholarworks@sjsu.edu. 


\author{
A Thesis \\ Presented to \\ The Faculty of the Department of Marine Science \\ San José State University
}

\author{
In Partial Fulfillment \\ of the Requirements for the Degree \\ Master of Science
}

by

Sara E. Worden

December 2015 
(C) 2015

Sara E. Worden

ALL RIGHTS RESERVED 
The Designated Thesis Committee Approves the Thesis Titled

EFFECTS OF SMALL-SCALE SUBSTRATE COMPLEXITY AND HETEROGENEITY ON ROCKY INTERTIDAL SPECIES INTERACTIONS

by

Sara E. Worden

\section{APPROVED FOR THE DEPARTMENT OF MARINE SCIENCE} SAN JOSÉ STATE UNIVERSITY

December 2015

$\begin{array}{ll}\text { Dr. Michael Graham } & \text { Moss Landing Marine Laboratories } \\ \text { Dr. Ivano Aiello } & \text { Moss Landing Marine Laboratories } \\ \text { Dr. Peter Raimondi } & \text { University of California, Santa Cruz }\end{array}$




\title{
ABSTRACT \\ EFFECTS OF SMALL-SCALE SUBSTRATE COMPLEXITY AND HETEROGENIETY ON ROCKY INTERTIDAL SPECIES INTERACTIONS
}

\author{
by Sara E. Worden
}

The barnacle assemblage in the high rocky intertidal zone has provided an excellent study system to examine species interaction webs. This assemblage consists of a small set of species: barnacles, a variety of macroalgae, and a suite of limpet grazers. Despite the extensive intertidal research occurring along the central California coast, little is known about this specific interaction web and what physical factors may influence it in this region. This study examines the direct, indirect, positive, and negative interactions between the intertidal barnacle Balanus glandula Darwin, the brown seaweed Pelvetiopsis limitata Gardner, and limpet grazers, and how the underlying rock type may affect this interaction web at two sites in central California. Results illustrate a significant, positive effect of $B$. glandula on macroalgal colonization at one site, while limpet grazers appear to be partially driving successful $P$. limitata recruitment at the other site. Targeted species also appear to be utilizing the substrate at each site differently, suggesting that variation in small-scale complexity and heterogeneity of the underlying rock type plays a role in shaping this interaction web. 


\section{ACKNOWLEDGEMENTS}

I have many individuals to thank for supporting me through the orchestration and completion of this research. Many thanks to my thesis advisor Dr. Mike Graham. I decided to pursue a degree at Moss Landing in order to strengthen my skills as an ecologist and deepen my understanding of the scientific method, and Mike was the perfect teacher to help me do so. And I so enjoyed sharing our passion for natural history and seaweed! My first day of class at Moss Landing was spent with Dr. Ivano Aiello in his geological oceanography class. Our initial conversations and my resulting class project regarding the role of rock type in rocky intertidal communities

were the foundation for this thesis research, and Ivano was more like a second advisor to me than a committee member. I never thought I could love something dead like a rock nearly as much I love seaweed! Lastly, I cannot begin to thank my third committee member, Dr. Pete Raimondi. Pete was my first scientific mentor as an undergraduate at UC Santa Cruz, and has continued to act as a mentor through it all! The opportunities he provided me throughout my career-from trips to the intertidal in Santa Cruz, to a field quarter on the coral reefs of French Polynesia, to years of employment as an intertidal research specialist — truly helped shape the young scientist I am today.

Funding from the David and Lucille Packard Foundation, the Dynegy Corporation, Friends of Moss Landing Marine Labs, the Moss Landing Marine Labs Student Body Association and the Dr. Earl H. Myers and Ethel M. Myers Oceanographic and Marine Biology Trust helped make this work possible. 
Many thanks to my lab mates - the BEERPIGs - for comments, ideas and inspiration during lab meetings and our lunch time lab dates. The Phycology Lab is a unique entity at Moss Landing, and I was lucky to be a BEERPIG (Benthic Ecology and Experimental Research, Phycology in General), a title that will never leave me, even after I graduate. And thanks to the well-oiled machine that is Moss Landing Marine Labs. From the library to the shop, this research would not have happened without the support of the staff and faculty that provide what's needed for the students at Moss Landing to carry out their research.

Finally, I certainly could not have done this without the research advice, field help, home cooked meals, laughs and love of my beloved friends and family. 


\section{TABLE OF CONTENTS}

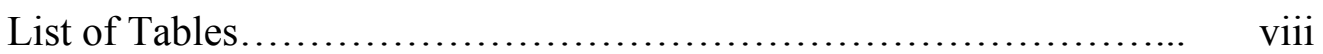

List of Figures.......................................... ix

Introduction.................................................. 1

Methods

Study Sites.............................................. 9

Experimental Design and Set-up............................ 10

Data Collection and Analysis

Pelvetiopsis limitata Recruitment and Substrate.......... 14

Grazer Density, Species Assemblages and Size Classes... 16

Humidity Measurements........................... 17

Results

Pelevtiopsis limitata Recruitment and Substrate.................. 19

Grazer Density, Species Assemblages and Size Classes.......... 31

Humidity Measurements.................................... 35

Discussion............................................... 36

Conclusion.................................................... 48

Literature Cited............................................ 50 


\section{LIST OF TABLES}

Table 1. Descriptions of species interactions described in previous studies of the barnacle-fucoid-grazer assemblage......................... 3

Table 2. Observed and published sizes of Pelvetiopsis limitata recruits, adult Balanus glandula and the Lottia complex of adult limpet grazers.............. 9

Table 3. Number of Pelvetiopsis limitata recruits in each treatment at the peak time of recruitment in April 2014 at Waddell Creek...................... 20

Table 4. Multiple Comparisons (Tukey's HSD) of treatment effects at Waddell Creek

Table 5. Number of Pelvetiopsis limitata recruits in each treatment and average recruitment within each treatment on barnacle and rock...

Table 6. Number of Pelvetiopsis limitata recruits in each treatment at the peak time of recruitment in April 2014 at Soberanes Point

Table 7. Multiple Comparisons (Tukey's HSD) of treatment effects at Soberanes Point

Table 8. Number of Pelvetiopsis limitata recruits in each treatment and average recruitment across each treatment on barnacle and rock...

Table 9. Limpet species assemblages and size classes at Waddell Creek and Soberanes Point counted and identified at the end of the experiment..... 


\section{LIST OF FIGURES}

Figure 1. Diagram illustrating the current paradigm for the species interaction web between Pelvetiopsis limitata recruits, Balanus glandula, and limpet grazers

Figure 2. Experimental block of 4 treatments, treatment control and unmanipulated control on Santa Cruz Mudstone at Waddell Creek, post experimental manipulation.

Figure 3. Experimental block 4 with 6 randomly placed treatments in the intertidal at Waddell Creek

Figure 4. A $30 \mathrm{~cm}$ diameter circular quadrat constructed from plastic sprinkler tubing

Figure 5. The $30 \mathrm{~cm}$ diameter circular quadrat with numbered quadrants, $1-10 \ldots \quad 18$

Figure 6. Pelvetiopsis limitata recruitment from April 2013-September 2014 at Waddell Creek

Figure 7. Bar graph of \# of Pelvetiopsis limitata recruits $/ \mathrm{cm}^{2}$ averaged across each treatment and square root transformed.

Figure 8. Average Pelvetiopsis limitata recruits $/ \mathrm{cm}^{2}$ across all treatments on barnacle and rock at the time of peak recruitment at Waddell Creek in April 2014... 23

Figure 9. Pelvetiopsis. limitata recruitment from April 2013-September 2014 at Soberanes Point.

Figure 10. Bar graph of \# of Pelvetiopsis limitata recruits $/ \mathrm{cm}^{2}$ averaged across each treatment and square root transformed........................... 27

Figure 11. Average Pelvetiopsis limitata recruits $/ \mathrm{cm}^{2}$ across all treatments on barnacle and rock at Soberanes Point at the time of peak recruitment in April 2014

Figure 12. Average limpet densities over time at Waddell Creek and Soberanes Point

Figure 13. Average limpet densities in all treatments of each species at Waddell Creek and Soberanes Point. 


\section{LIST OF FIGURES continued}

Figure 14. Average \# of limpets separated by size class in all treatments at Waddell Creek and Soberanes Point.......................................... 34

Figure 15. Average relative humidity per plot at Waddell Creek and Soberanes

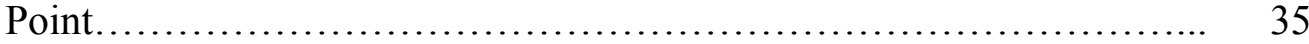

Figure 16. Species interactions webs that depict interaction webs for a) the current paradigm and interactions that occurred at b) Waddell Creek and

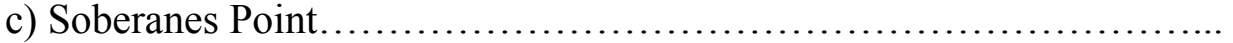




\section{Introduction}

The rocky intertidal is a dynamic environment in which marine organisms experience variable stress from physical, biological, and chemical processes (Dayton, 1971). Countless studies have been conducted to determine how such processes influence community and population ecology in the rocky intertidal zone. For example, studies have shown that an intertidal organism's life history can be shaped by physical stressors such as wave exposure (Denny, 1995; Friedland \& Denny, 1995; Helmuth \& Denny, 2003), temperature (Kordas, Harley, \& O'Connor, 2011; McQuaid \& Branch, 1984), and desiccation (Harley \& Helmuth, 2003). Organisms living in rocky intertidal environments experience extreme shifts and variability in these stressors daily as the tide goes in and out. This extreme variability further influences rocky intertidal organismal life history and overall community structure (Denny, 1995; R. T. Paine \& Simon, 1981). Adaptation to stress often results in complex species interactions between organisms that can ameliorate the effects of the rapidly shifting environment (Bruno, Stachowicz, \& Bertness, 2003). Such species interactions can play an important role in the rocky intertidal as they often affect succession and recovery after a disturbance and can shift distributional limits within the intertidal zone (Connell \& Slatyer, 1977).

There are two types of species interactions: direct and indirect. Direct species interactions occur when one species directly affects the abundance and behavior of another; indirect interactions occur when one species affects another by altering the abundance or behavior of a third species (Farrell, 1991; BA Menge, 1997; Wootton, 1994, 2002). Both direct and indirect species interactions can have positive or negative 
effects on the organisms involved. Defining these interactions can often be challenging due to the complexity of natural systems and confounding factors that may conceal such interactions (Connell, 1972; Wootton, 1993). However, the importance of understanding species interactions and the factors influencing them can not be dismissed because of the insight it may provide regarding how ecosystems recover after a disturbance and how they may adapt to an increase in environmental stress (Connell \& Slatyer, 1977; Harley, 2008; Harley \& Helmuth, 2003).

The barnacle assemblage is commonly used to study species interactions in the rocky intertidal (A. R. O. Chapman, 1989, 1990; Dayton, 1971; Dungan, 1986; Geller, 1991; Jernakoff, 1983, 1985; Kim, 1997; Lubchenco, 1983). This system generally includes a small set of species consisting of barnacles (e.g., Balanus glandula Darwin), an intertidal fucoid (e.g., Pelvetiopsis limitata Gardener), and a suite of invertebrate grazers (e.g., Lottia species). Multiple studies have been conducted on this assemblage or pairs of species in this assemblage, exploring how each organism affects the others and what these effects may mean for community structure in the upper intertidal (Anderson, 1999; Brock, Nylund, \& Pavia, 2007; A. R. O. Chapman, 1989, 1990; Dayton, 1971; M.N. Dethier \& Duggins, 1984; Megan N. Dethier, Williams, \& Freeman, 2005; Duffy \& Hay, 1990; Dungan, 1986; Geller, 1991; Jernakoff, 1983, 1985; Kim, 1997; Lubchenco, 1983). These studies have resulted in the definitions and observations of direct, indirect, positive, and negative interactions between each of these species (Table 1). 
Table 1. Descriptions of species interactions described in previous studies of the barnacle-fucoid-grazer assemblage. Defines direct, indirect, positive, and negative interactions observed between each species and if the interaction was supported and statistically tested in the literature. Interactions in bold were addressed by this study.

\begin{tabular}{|c|c|c|c|c|c|c|}
\hline Species & Interaction & Direct & Indirect & Positive & Negative & Supported? \\
\hline $\begin{array}{l}\text { Fucoid vs. } \\
\text { Barnacle }^{1,2,3}, \\
4\end{array}$ & $\begin{array}{l}\text { Barnacles facilitate algal } \\
\text { recruitment by providing } \\
\text { refuge from physical factors } \\
\text { and altering substrate }\end{array}$ & $\mathbf{X}$ & & $\mathbf{X}$ & & $\mathbf{X}$ \\
\hline $\begin{array}{l}\text { Fucoid vs. } \\
\text { Barnacle }^{2,3,4}\end{array}$ & $\begin{array}{c}\text { Barnacles alter grazing } \\
\text { behavior of invertebrate } \\
\text { grazers } \\
\end{array}$ & & $\mathbf{X}$ & $\mathbf{X}$ & & $\mathbf{X}$ \\
\hline $\begin{array}{l}\text { Fucoid vs. } \\
\text { Barnacle }^{1}\end{array}$ & $\begin{array}{l}\text { Adult fucoids inhibit } \\
\text { recruitment of barnacles }\end{array}$ & $X$ & & & $\mathrm{X}$ & $\mathrm{X}$ \\
\hline $\begin{array}{l}\text { Fucoid vs. } \\
\text { Grazer }^{1,2,3,4}\end{array}$ & $\begin{array}{c}\text { Grazers cause algal mortality } \\
\text { by eating fucoid spores and } \\
\text { recruits }\end{array}$ & $\mathbf{X}$ & & & $\mathbf{X}$ & $\mathbf{X}$ \\
\hline $\begin{array}{l}\text { Fucoid vs. } \\
\text { Grazer }^{5} 6\end{array}$ & $\begin{array}{l}\text { Grazers eat ephemeral algae } \\
\text { and free up space for fucoid } \\
\text { settlement }\end{array}$ & & $X$ & $\mathrm{X}$ & & $\mathrm{X}$ \\
\hline $\begin{array}{l}\text { Fucoid vs. } \\
\text { Grazer }{ }^{7}\end{array}$ & $\begin{array}{l}\text { Adult fucoids provide refuge } \\
\text { for grazers from physical stress }\end{array}$ & $\mathrm{X}$ & & $\mathrm{X}$ & & \\
\hline $\begin{array}{l}\text { Barnacle vs. } \\
\text { Grazer }^{2,3,4}\end{array}$ & $\begin{array}{l}\text { Barnacles alter substrate } \\
\text { making grazing difficult }\end{array}$ & $\mathbf{X}$ & & & $\mathbf{X}$ & $\mathbf{X}$ \\
\hline $\begin{array}{l}\text { Barnacle vs. } \\
\text { Grazer }^{1}\end{array}$ & $\begin{array}{l}\text { Grazers bulldoze barnacle } \\
\text { recruits while feeding }\end{array}$ & $\mathrm{X}$ & & & $\mathrm{X}$ & $\mathrm{X}$ \\
\hline
\end{tabular}

${ }^{1}$ Dayton, P.K. 1971. Competition, Disturbance, and Community Organization: The Provision and 41: 351-389.

${ }^{2}$ Lubchenco, J. 1983. Littorina and fucus: effects of herbivores, substratum heterogeneity, and plant escapes during succession. Ecology 64: 1116-1123.

${ }^{3}$ Kim, J.H. 1997. The role of herbivory, direct and indirect interactions, in algal succession. Journal of Experimental Marine Biology and Ecology 217:119-135.

${ }^{4}$ Jernakoff, P. 1985. An experimental evaluation of the influences of barnacles, crevices, and seasonal patterns of grazing on algal diversity and cover in an intertidal barnacle zone. Journal of Experimental Marine Biology and Ecology 88:287-302.

${ }^{5}$ Connell, J.H., and R.O. Slatyer. 1977. Mechanisms of Succession in Natural Communities and Their Role in Community Stability and Organization. The American Naturalist 111:1119-1144.

${ }^{6}$ Szoboszlai, A. 2008. Positive and Negative Effects of Intertidal Algal Canopies on Fucoid Recruitment. Moss Landing Marine Laboratories Masters Thesis, San Jose State University.

${ }^{7}$ Stachowicz, J.J. 2001. Mutualism, Facilitation, and the Structure of Ecological Communities. BioScience 51:235-246. 
This study addressed and defined several interactions between the barnacle B. glandula, recruits of the fucoid alga $P$. limitata, and a suite of limpet grazers in the genus Lottia (Figure 1).

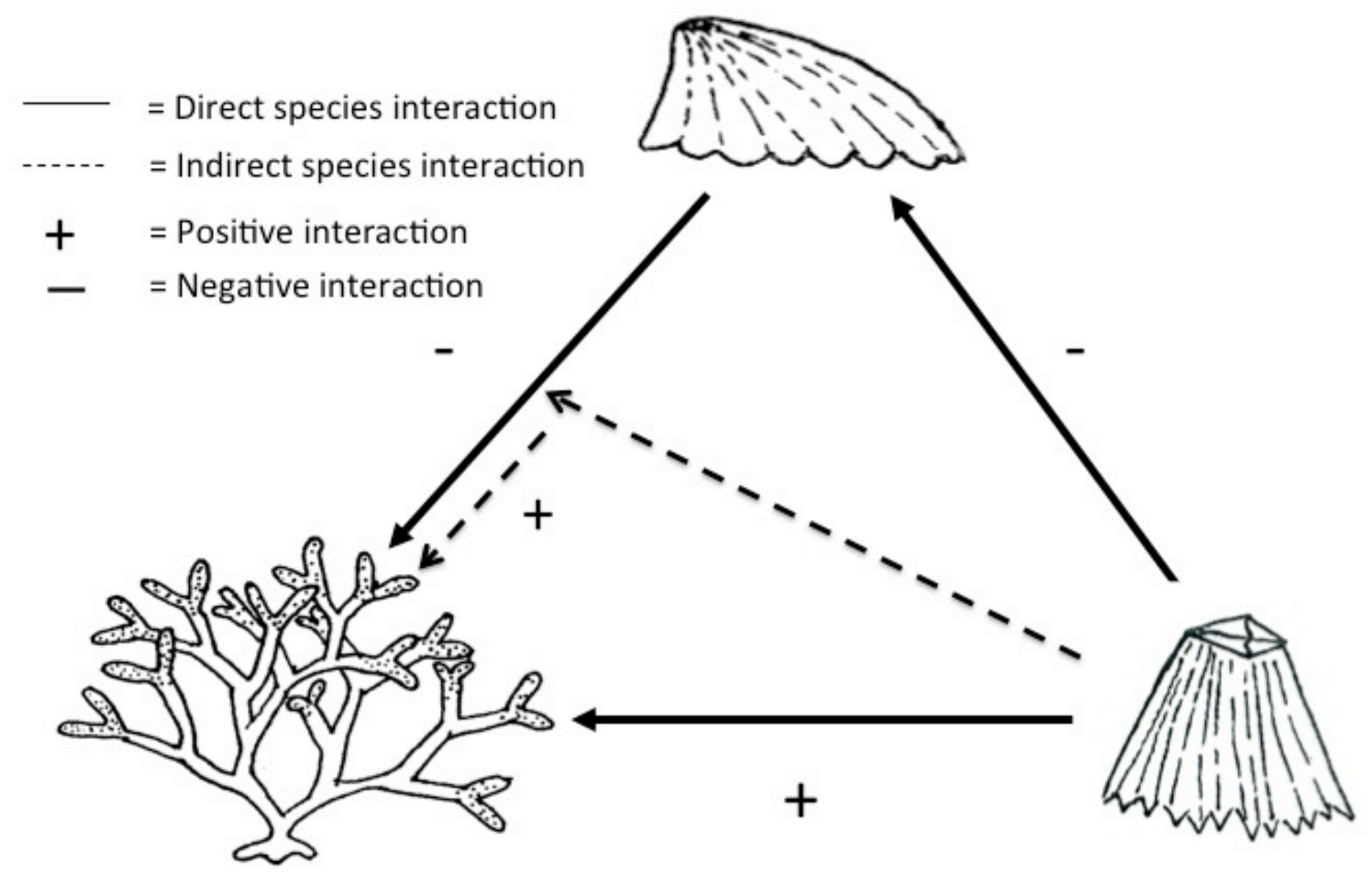

Figure 1. Diagram illustrating the current paradigm for the species interaction web between Pelvetiopsis limitata recruits (bottom left), Balanus glandula (bottom right) and limpet grazers (top). Each arrow represents a single interaction, and points towards the species affected by that interaction.

Several studies defined a direct, positive interaction between the barnacle and the fucoid in that the barnacle, an early successional species, facilitates the colonization of the fucoid, a late successional species, by providing both a refuge from desiccation and temperature shifts, and a suitable place for attachment (Dayton, 1971; Kim, 1997; 
Lubchenco, 1983). Moreover, this facilitation is likely due to the alteration of smooth substrates by barnacle tests, creating a more suitable habitat for algal settlement (Jernakoff, 1985; Lubchenco, 1983). Alteration of the substrate by the barnacle also makes grazing on algal recruits more difficult for invertebrates (Jernakoff, 1985; Kim, 1997; Lubchenco, 1983), a direct, negative interaction between the barnacle and invertebrate grazers. This interaction drives an indirect, positive interaction between the barnacle and the fucoid, as the barnacle benefits the fucoid by altering the behavior of the grazer (Jernakoff, 1985; Kim, 1997; Lubchenco, 1983). Finally, a direct, negative interaction occurs between the limpet grazer and the fucoid, as grazing activity causes fucoid mortality (Dayton, 1971; Jernakoff, 1985; Kim, 1997; Lubchenco, 1983).

This species interaction web has been well studied over a large bio-geographical range, yet has rarely been addressed in California. Furthermore, the evidence that both indirect and direct species interactions can exist between B. glandula, P. limitata, and Lottia spp., and that these interactions can have both negative and positive effects, stresses the importance of further investigation into this community.

Although the barnacle-fucoid-grazer interaction web depicted in Figure 1 has been well studied, it is unknown whether the strength or direction of interactions vary as a function of physical factors such as the substrate type on which these intertidal benthic communities exist. All studies to date have been conducted on smooth substrates, primarily sandstones and mudstones, and note the potential importance of substrate heterogeneity and complexity in shaping intertidal community structure and species distributions (Carlson, Shulman, \& Ellis, 2006; Espinosa, Rivera-Ingraham, \& Garcia- 
Gomez, 2011; Gaines, Brown, \& Roughgarden, 1985; Kim, 1997; Lubchenco, 1983), but did not characterize the physical substratum or test its effects on benthic communities. The scale at which substratum may be affecting intertidal community structure is also uncertain. Recent studies have noted the potentially large-scale effects on intertidal community structure of the underlying substrate topography of intertidal habitats and how this topography may influence the ecological processes occurring in these communities (Gedan, Bernhardt, Bertness, \& Leslie, 2011; Harley, 2008; C. Robles \& Desharnais, 2002; C. D. Robles, Desharnais, Garza, Donahue, \& Martinez, 2009; C. D. Robles, Garza, Desharnais, \& Donahue, 2010), however, little has been done on the effects of small-scale substrate heterogeneity and complexity. A few studies have described how geological complexity may interact with hydrological forces to influence rocky shore community dynamics (Charters, Neushul, \& Coon, 1973; O'Donnell \& Denny, 2008), and how thermal properties of the underlying rock affect the organisms that live on it (Bergeron \& Bourget, 1986; Chapperon \& Seuront, 2011; Coombes \& Naylor, 2012; Raimondi, 1988), but the direct effects of small-scale topography on any given rocky intertidal community are not well understood.

Previous observations on the barnacle-grazer-algae interaction web have noted that some interactions between these species may be due to the alteration of a smooth substrate by the barnacle (Jernakoff, 1985; Kim, 1997; Lubchenco, 1983), yet this interaction web has never been studied across substrates with varying surface complexity. A rocky intertidal zone with a more heterogeneous rock surface may alter the strengths and/or directions of interactions depicted in Figure 1 by providing a similar habitat as a 
barnacle test for algal spores. Given that species interactions in the high intertidal are often driven by physical stressors (e.g. extreme temperature and desiccation) (Kordas et al., 2011) that may be ameliorated or facilitated by certain characteristics of the underlying rock, such as thermal properties (Gedan et al., 2011) and surface complexity, I hypothesized that the interactions between these species in the high intertidal would vary as a function of substrate type.

Due to the knowledge gap concerning this interaction web on the central California coast, the first objective of this study was to describe species interactions (direct, indirect, positive, and negative) between Pelvetiopsis limitata, Balanus glandula, and limpet grazers in the rocky intertidal in central California. To investigate this objective, I tested the following hypothesis in a manipulative field experiment: $\mathbf{H}_{1}$ : P. limitata recruitment will change in the presence or absence of $B$. glandula and limpet grazers.

The second objective of this study was to determine if the interactions between these species would vary due to the possible effects of small-scale substrate complexity and heterogeneity. The California coastline presents a unique opportunity to further our understanding of how rock type may influence the ecological processes in the intertidal because of its geological diversity. The rock type in one intertidal zone may vary across such small scales as meters (Wheeler, 2015). This variation in rock type leads to variation in geological characteristics such as surface complexity, a physical feature that is often not included in ecological studies in the intertidal due to the difficulty in quantifying it. I hypothesized that: 
$\mathbf{H}_{2}$ : The strengths of correlation between $P$. limitata recruitment and B. glandula in the presence of limpet grazers will be lower on smooth vs. rough surfaces.

Experiments were specifically designed to test if the barnacle-fucoid-grazer interaction web in central California functioned similarly to those described in other regions, and if interactions between these species differed between geographic locations with varying lithologies. Although similar species assemblages occur in central California as in other temperate intertidal ecosystems, addressing these hypotheses showed that interactions between species varied and functioned differently than those in other regions, and provided insights as to a possible cause driving this variation.

\section{Methods}

\section{Study Sites}

To test these hypotheses, I chose two intertidal sites composed of different rock types and where the targeted species occurred. The first of these sites was Waddell Creek, which was about 20 miles north of Santa Cruz, CA. The intertidal benches there were comprised of Santa Cruz Mudstone of the late Miocene age (Hayes \& Michel, 2010), a siliceous, sedimentary rock commonly found north of the Monterey Bay between Santa Cruz and Año Nuevo State Park. The surface of the Santa Cruz Mudstone boasts minimal surface complexity on a millimeter-centimeter scale, and relative to the size of the study organisms, is effectively smooth. The barnacle-fucoid-grazer interaction web has classically been tested on smooth substrates (Dayton, 1971; Dungan, 1986; Kim, 1997; Lubchenco, 1983); therefore experiments conducted at Waddell Creek were specifically designed to test whether the basic species interaction web in central 
California was similar to that described in other regions. To test how increased surface complexity and heterogeneity may alter this species interaction web, I replicated the same experiment at a second site, Soberanes Point, located about 12 miles south of the Monterey Peninsula, CA. The intertidal there is comprised of granodiorite, an intrusive, plutonic rock found in intermittent outcrops from the Big Sur coast to Bodega Bay, CA (Alt and Hyndman 2000). Granodiorite boasts large, visible feldspar crystals creating increased surface complexity and heterogeneity on a millimeter-centimeter scale, which was considered rough relative to the size of the study organisms (Table 2).

Table 2. Observed and published sizes of Pelvetiopsis limitata recruits, adult Balanus glandula and the Lottia complex of adult limpet grazers.

Species

Pelvetiopsis limitata ${ }^{l}$

Balanus glandula ${ }^{2}$

Lottia digitalis/austrodigitalis $^{3}$

Lottia paradigitalis ${ }^{3}$

Lottia scabra ${ }^{3}$

Lottia pelta $^{3}$

\section{Morphological Characteristic}

Thallus Height (mm)

$0.5-20$

Basal Plate Diameter (mm)

$\leq 22$

Shell Length (mm)

10-25

$5-20$

10-30

20-45
Holdfast Diameter (mm)

0.5-2

Shell Height (mm)

$\leq 15$

Apex Height (mm)

$\leq 10$

$\leq 8$

$\leq 10$

$\leq 20$

\footnotetext{
${ }^{1}$ Due to lack of data in the literature on sizes of $P$. limitata recruits, measurements are based on personal observations.

${ }^{2}$ Smith, R., and J. Carlton, editors. 2007. The Light and Smith Manual: Intertidal Invertebrates from Central California to Oregon. University of California Press.

${ }^{3}$ Lindberg, D. 1981. Acmaaeidae Gastropoda Mollusca: Intertidal Invertebrates if the San Francisco Bay Estuary System. The Boxwood Press
} 
This experiment was designed to test if the interaction web between Pelvetiopsis limitata, Balanus glandula, and limpet grazers (Figure 1) differed between Waddell Creek and Soberanes Point. Substrate type was not directly replicated, but as one of the primary physical factors that differed between these sites, it was considered as a potential driver affecting this species interaction web.

\section{Experimental Design and Set-up}

Experimental manipulations at each site consisted of four treatments and two controls (one unmanipulated, one artifact control), with five replicates each. Treatments manipulated the presence and absence of barnacles and limpet grazers to test the effects of these species on Pelvetiopsis limitata recruitment. Treatments and controls (Figure 2) were as follows:

1. Barnacles present, grazers present

2. Barnacles present, grazers absent

3. Barnacles absent, grazers present

4. Barnacles absent, grazers absent

5. Artifact control with all species present

6. Unmanipulated control with all species present

Exclusion fences made of copper sheet metal were erected to deter grazers from entering grazer exclusion plots, and barnacles were manually removed from treatments. 


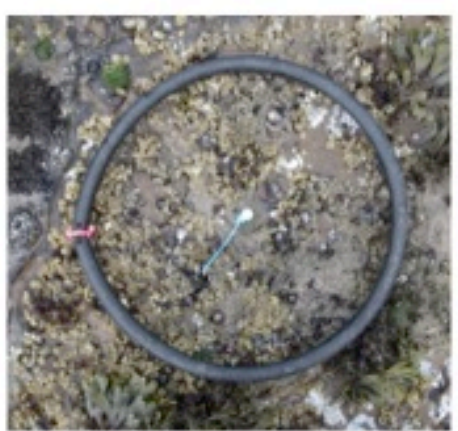

Treatment 1:

+Barnacles, +Grazers

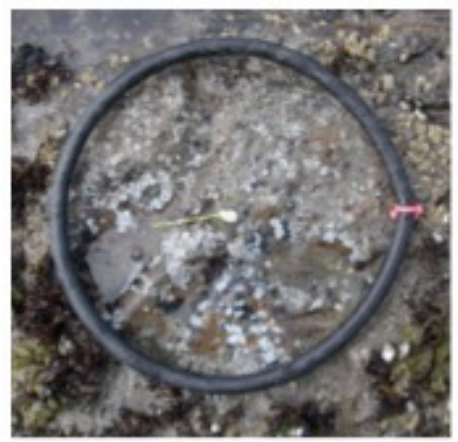

Treatment 3:

-Barnacles, +Grazers

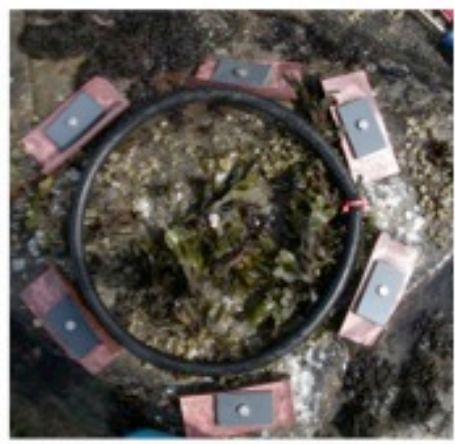

Treatment 5 :

Treatment Control

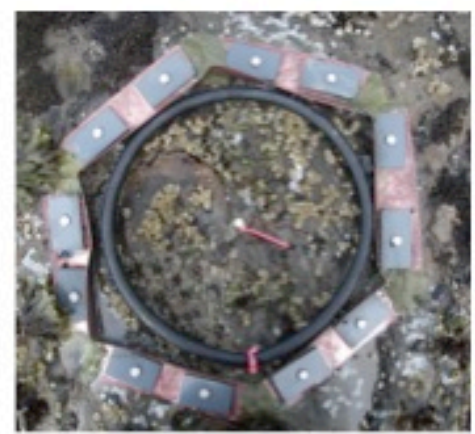

Treatment 2:

+Barnacles, -Grazers

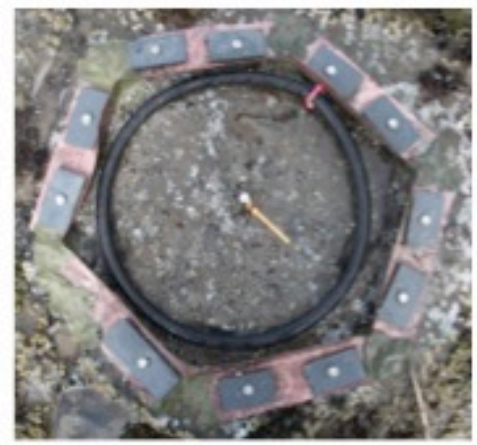

Treatment 4:

-Barnacles, -Grazers

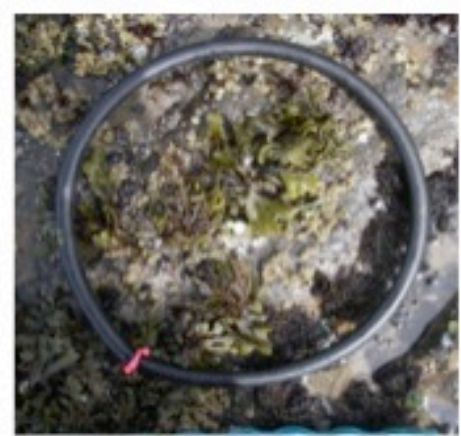

Treatment 6:

Un-manipulated

Control

Figure 2. Experimental block of 4 treatments, treatment control, and unmanipulated control on Santa Cruz Mudstone at Waddell Creek, post experimental manipulation. Pelvetiopsis limitata, Balanus glandula, and limpet grazers were present in each plot prior to manipulation. Copper fences are visible in grazer exclusion plots (treatments 2 and 4) and the treatment control (treatment 5). The black circles denote the $30 \mathrm{~cm}$ diameter plot area. 
Copper sheet metal ( $0.549 \mathrm{~mm}$ thick), commonly used for roofing and other decorative purposes, was used. Copper has been commonly used in intertidal experiments to deter gastropod grazers (M.N. Dethier \& Duggins, 1984; Kim, 1997). Copper exclusion fences were installed by drilling holes in the rock using a battery operated rock hammer drill and inserting plastic wall anchors into the drilled holes. Copper fences were then bolted to the substrate using stainless steel bolts screwed into the wall anchors and PVC washers. Any spaces between the copper and rock surface were sealed using marine epoxy (Z-spar brand). Adult $P$. limitata was removed from all plots to eliminate the potential effects, such as shading, of the adults on P. limitata recruitment.

There was one unmanipulated control and one artifact control for each block to test the possible effects of the copper siding on P. limitata colonization in the exclusion plots. The artifact control had six equally spaced pieces of copper siding around the plot, placed $5 \mathrm{~cm}$ apart, so grazers could move in and out freely. Treatment locations were randomly selected at each site in the high intertidal zone and followed a randomized block design. A randomized block design was chosen because physical conditions in the rocky intertidal can be highly variable across small scales. Blocking reduces the effects of this variability such that the spatial variation within blocks is less than the variability between blocks because treatments within any given block experience similar conditions. This helps reduce possible confounding of the treatment effects by variables that can't be controlled, like wave force or temperature. There were five blocks at each site, each block containing 1 replicate of each of the 6 treatments (Figure 3). 


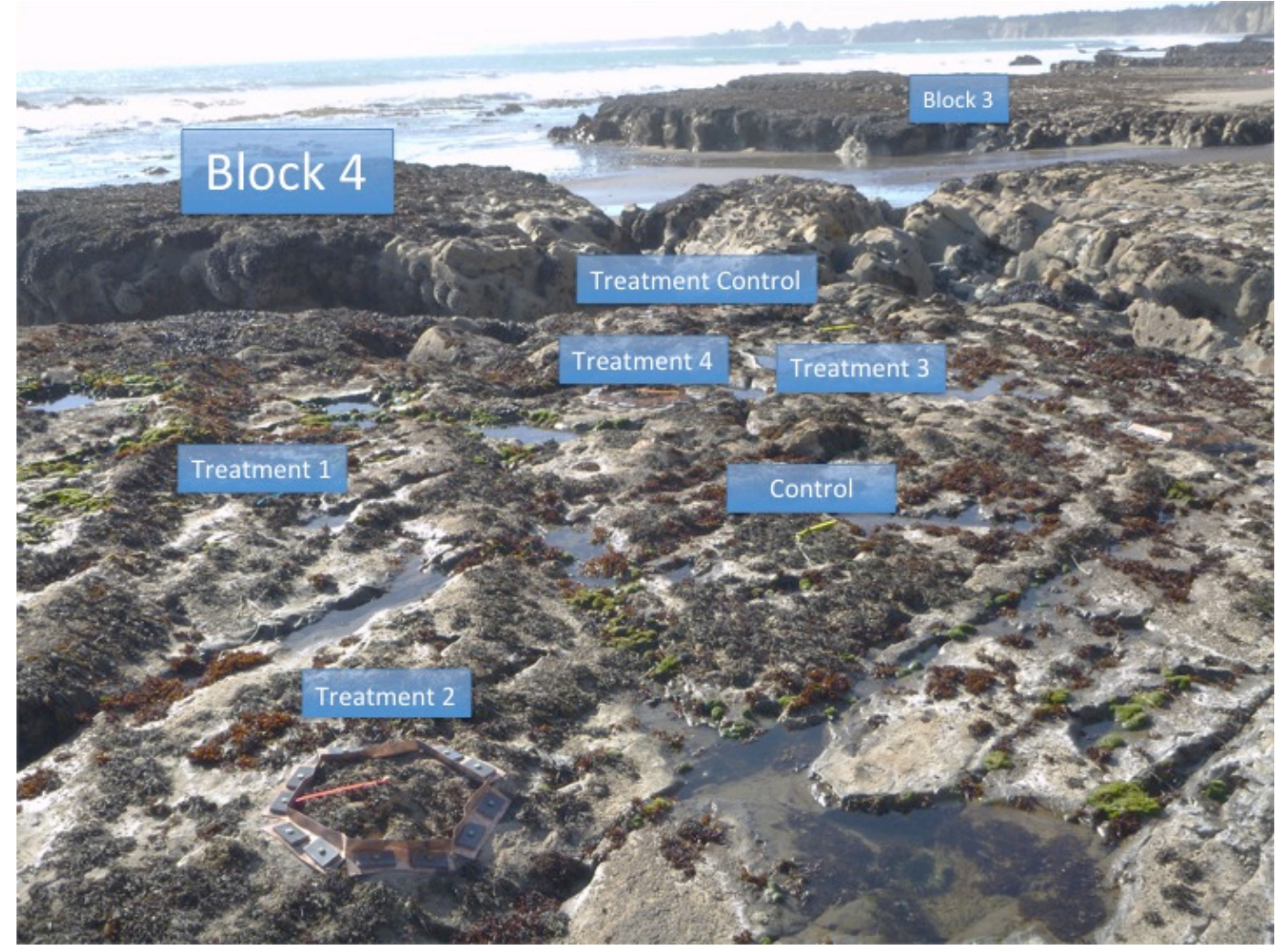

Figure 3. Experimental Block 4 with 6 randomly placed treatments in the intertidal at Waddell Creek. The distance between treatments in this block varied from 0.5-1 meters. Block 3 was placed 20 meters up coast, with Blocks 1 and 2 further up coast from Block 3. Block 5 was just down coast from Block 4.

Distance between blocks varied from 1-20 meters based on available space in the rocky intertidal for experimental set-up. Treatments within blocks were 0.5-3 meters apart, depending on how closely any given block occurred to a neighboring block. As randomized block design dictates, the distance between treatments in any given block never exceeded the distance between neighboring blocks (Zar, 1984). All three study species were present in each plot prior to manipulation. Percent cover of each organism prior to manipulation varied from $\sim 20-98 \%$, based on visual examination, as point contact sampling was not conducted before experimental plots were cleared. Circular 
plots with a $30 \mathrm{~cm}$ diameter were used because edge effects are smallest in circular plots vs. square or rectangular plots (Magurran, 1988). This decreased sampling biases associated with increased edge effects (Magurran, 1988). Sites were visited monthly for treatment maintenance, which entailed removing barnacle recruits in barnacle exclusion plots and repairing damaged copper fences. Data were collected every other month, depending on field conditions.

\section{Data Collection and Analysis}

\section{Pelvetiopsis limitata Recruitment and Substrate}

A $30 \mathrm{~cm}$ diameter circular quadrat was used to collect data on the percent cover of available recruitment substrate (Figure 4). Percent cover data were collected in each plot using random point contact (RPC) method with 50 points to obtain percent cover of barnacles and bare rock. Pelvetiopsis limitata recruits (up to $2 \mathrm{~cm}$ ) were counted in each plot and the type of attachment substrate (either rock or barnacle) where recruits occurred was recorded. P. limitata recruits were removed from each treatment every couple of months after sampling in order to capture new recruitment events over the course of the study. Therefore, recruitment occurring during one sampling period was independent from recruitment events during other sampling periods.

To examine trends in $P$. limitata recruitment over time at both sites, the average P. limitata recruitment $/ \mathrm{cm}^{2}$ observed in each treatment was calculated. First, the area of the $30 \mathrm{~cm}$ diameter quadrat was calculated $\left(\right.$ area $\left.=706.858 \mathrm{~cm}^{2}\right)$. To calculate the number of recruits $/ \mathrm{cm}^{2}$ in each treatment, the total \# of recruits was divided by the area of the 
plot. Average number of recruits $/ \mathrm{cm}^{2}$ for each treatment was then plotted in order to examine recruitment trends over time at both sites.

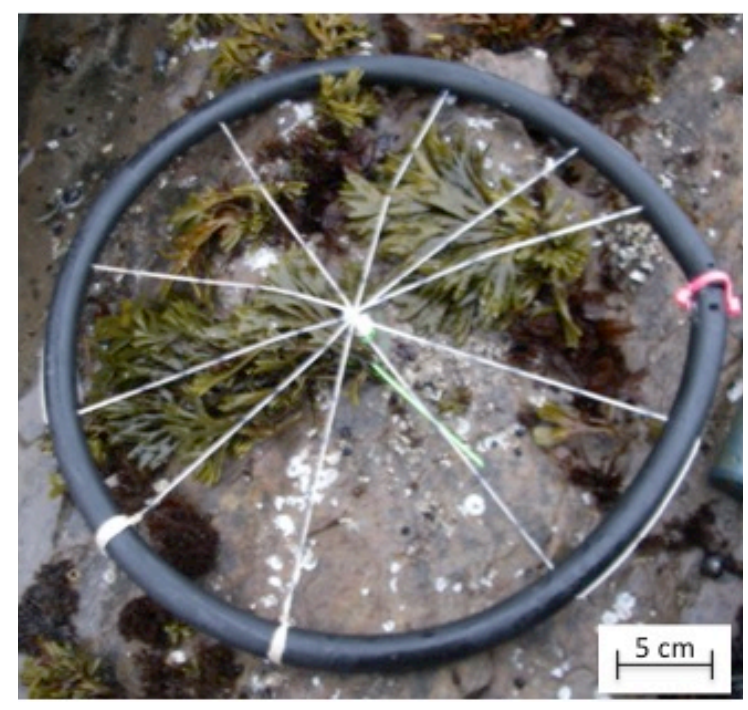

Figure 4. A $30 \mathrm{~cm}$ diameter circular quadrat constructed from plastic sprinkler tubing. The quadrat was strung, and five points were randomly placed along each string between the edge and center of the quadrat for a total of 50 points.

To test the effects of the presence/absence of barnacles and grazers on P. limitata recruitment, statistical analyses were run at the peak recruitment time point in April 2014. The peak recruitment time point was chosen for analyses because this study was not concerned with the effects of treatment on P. limitata recruitment over time. First, a randomized block analysis of variance (ANOVA) tested if blocking reduced confounding of the main treatment effect on $P$. limitata recruitment by uncontrollable variables. Oneway ANOVAs were then run to test the main effects of treatment on P. limitata recruitment at both sites and multiple comparisons (Tukey's HSD) were run to examine the differences between individual treatments. Recruitment data were square root 
transformed before statistical analysis to resolve high variance within treatments in the raw data.

To compare recruitment between substrate types, area in $\mathrm{cm}^{2}$ of available substrate of barnacles and rock were calculated for each plot by multiplying the percent cover of each substrate by total plot area (plot area $=706.858 \mathrm{~cm}^{2}$ ). For example, if any given plot had $50 \%$ barnacle cover, $0.5 * 706.858$ would render the area in $\mathrm{cm}^{2}$ of barnacles in that plot. Summing the number of recruits on barnacles and rock separately, then dividing this number by the substrate area calculated the number of recruits $/ \mathrm{cm}^{2}$ on each substrate. Two-sample t-tests were run for both sites to compare differences in total P. limitata recruitment on barnacle tests versus bare rock. Recruitment data were square root transformed before statistical analysis to resolve high variance within treatments in the raw data.

\section{Grazer Density, Species Assemblages, and Size Classes}

Limpet species assemblages and size distributions appeared to differ between sites over the course of the experiment. Several studies that focused on grazer effects on intertidal algal communities noted that grazer size and species identity played a role in the magnitude of these effects (Geller, 1991; Nicotri, 1977), so detailed data on limpet populations at each site were collected at the end of the experiment in Winter 2014. Limpets were counted, identified to species, and classified into three size classes in each treatment that included grazers. The most common species present in these treatments were Lottia austrodigitalis-digitalis Rathke complex, L. paradigitalis Fritchman, L. scabra Gould, and L. pelta Rathke. Size classes were defined based on intertidal 
monitoring protocols provided by the Partnership for Interdisciplinary Studies of Coastal Oceans (PISCO) and were small $(<5 \mathrm{~mm})$, medium $(5-15 \mathrm{~mm})$, and large $(>15 \mathrm{~mm})$.

To examine trends in limpet densities over time between treatments where limpets were present, number of limpets $/ \mathrm{cm}^{2}$ in each treatment were first calculated by dividing the total number of limpets in each plot by the total plot area, averaged within treatments and plotted. Two-sample t-tests tested for differences in individual limpet species assemblages and limpet size classes between sites.

\section{Humidity Measurements}

During the length of the experiment, water was occasionally observed collecting in the grazer exclusion plots after low tide at Soberanes Point $(<5 \mathrm{~mm}$ in depth observed), likely because it was not able to drain entirely from the enclosed copper fences. This may have contributed to an increase in humidity in these plots. A few studies showed that a steep increase in humidity and/or submersion in water could be deleterious to the germination success of fucoid spores of high-shore dwelling species such as Pelvetiopsis limitata (A.R.O Chapman, 1995; Rugg \& Norton, 1987). Very little P. limitata recruitment was observed in treatments with enclosed, copper fences over the course of the experiment, so humidity data were collected at the end of the experiment in order to test for potential effects of increased humidity in grazer exclusion treatments. Humidity measurements were taken using a Fisher Scientific Traceable Hygrometer ${ }^{\circledR}$. Measurements were taken in all treatments at both sites during a low tide series in Winter 2014. Using the random point contact (RPC) circular quadrat, random humidity measurements were taken in each treatment. The strings on the RPC quadrat divided the 
circle into ten sections (Figure 5). These sections were labeled 1-10, and a random numbers generator assigned three out of ten sections in each treatment to take humidity measurements in. Measurements were taken $1 \mathrm{~cm}$ from the rock surface in the middle of each section. These measurements were taken in all treatments at two separate times during the low tide to capture changing physical conditions over the course of the tide. The three measurements were averaged to get average humidity in each treatment. A randomized block ANOVA tested for confounding by uncontrollable variables of the main treatment effects on humidity.

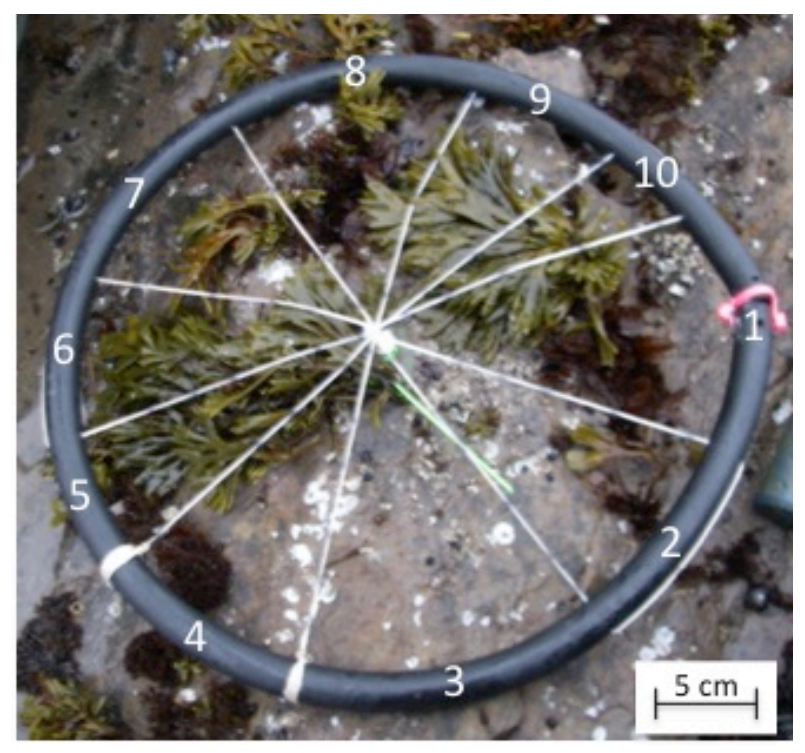

Figure 5. The $30 \mathrm{~cm}$ diameter circular quadrat with numbered quadrants, 1-10. A random numbers generator was used to select 3 out of the 10 sections to take humidity measurements in. 


\section{Results}

\section{Pelvetiopsis limitata Recruitment and Settlement Substrate}

\section{Waddell Creek}

Pelvetiopsis limitata recruitment was observed at both sites year round, but

showed a clear seasonal trend with peak recruitment occurring during the spring sampling dates in 2013 and 2014. At Waddell Creek, the highest overall recruitment at each time point was observed in plots where barnacles were present, and little to no recruitment was observed in plots where barnacles were absent, regardless of the presence or absence of grazers (Figure 6).

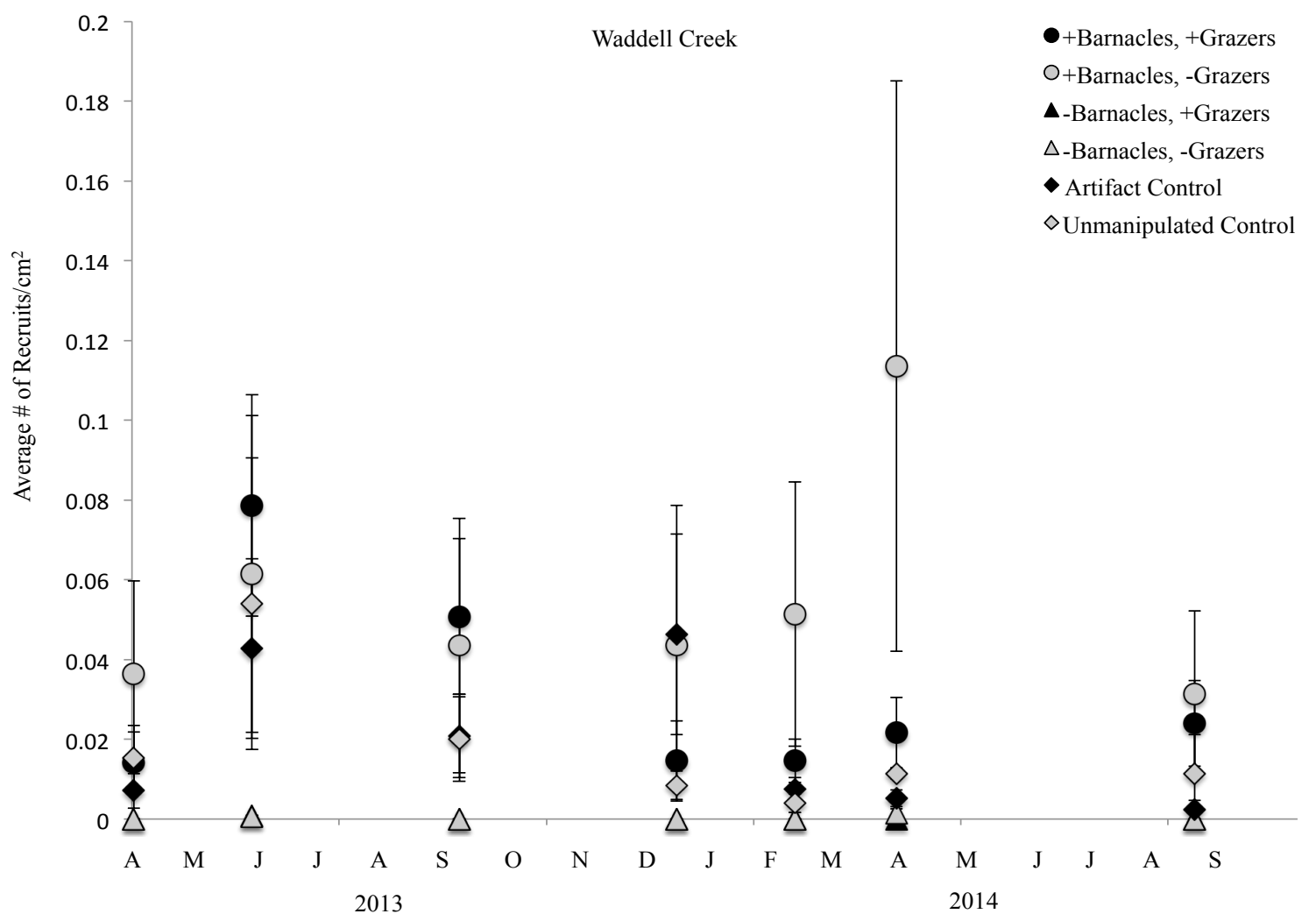

Figure 6. Pelvetiopsis limitata recruitment from April 2013-September 2014 at Waddell Creek. Peak recruitment events were observed in May 2013 and April 2014. Each point is the average \# of recruits $/ \mathrm{cm}^{2}$ across 6 treatments and error bars are standard error. 
At the time of peak recruitment in May of 2014 at Waddell Creek, P. limitata recruits were observed in three out of four treatments (Table 3 ).

Table 3. Number of Pelvetiopsis limitata recruits in each treatment at the peak time of recruitment in April 2014 at Waddell Creek.

\begin{tabular}{|c|c|c|c|}
\hline Treatment & Block & \# of Recruits & Mean $\pm \mathrm{SE}$ \\
\hline \multirow{5}{*}{$\begin{array}{c}1 \\
+ \text { Barnacles, }+ \text { Grazers }\end{array}$} & 1 & 32 & \\
\hline & 2 & 6 & \\
\hline & 3 & 1 & \\
\hline & 4 & 27 & \\
\hline & 5 & 9 & $15 \pm 6.11$ \\
\hline \multirow{5}{*}{$\begin{array}{c}2 \\
\text { +Barnacles, -Grazers }\end{array}$} & 1 & 4 & \\
\hline & 2 & 21 & \\
\hline & 3 & 14 & \\
\hline & 4 & 87 & \\
\hline & 5 & 268 & $78.8 \pm 49.5$ \\
\hline \multirow{5}{*}{$\begin{array}{c}3 \\
\text {-Barnacles, +Grazers }\end{array}$} & 1 & 0 & \\
\hline & 2 & 0 & \\
\hline & 3 & 0 & \\
\hline & 4 & 0 & \\
\hline & 5 & 0 & $0 \pm 0$ \\
\hline \multirow{5}{*}{$\begin{array}{c}4 \\
\text {-Barnacles, -Grazers }\end{array}$} & 1 & 0 & \\
\hline & 2 & 0 & \\
\hline & 3 & 1 & \\
\hline & 4 & 0 & \\
\hline & 5 & 4 & $1 \pm 0.77$ \\
\hline \multirow{5}{*}{$\begin{array}{c}5 \\
\text { Artifact Control }\end{array}$} & 1 & 1 & \\
\hline & 2 & 4 & \\
\hline & 3 & ND & \\
\hline & 4 & 6 & \\
\hline & 5 & ND & $5.3 \pm 1.45$ \\
\hline \multirow{5}{*}{$\begin{array}{c}6 \\
\text { Unmanipulated Control }\end{array}$} & 1 & 1 & \\
\hline & 2 & 2 & \\
\hline & 3 & 5 & \\
\hline & 4 & 1 & \\
\hline & 5 & 5 & $2.8 \pm 0.92$ \\
\hline
\end{tabular}


No recruitment was observed in treatment 3 , which excluded barnacles and included grazers. In blocks 3 and 5, treatment 5 (artifact control) experienced so much recruitment that individual recruits were impossible to isolate and count, so data were not collected and these two plots were excluded from the analysis. The randomized block ANOVA was not significant $(\mathrm{p}=0.26)$. No interaction between block and treatment is assumed in randomized block analysis, so there was no interaction term. A one-way ANOVA testing the main effect of treatment on P. limitata recruitment was significant $\left(\mathrm{F}_{4,18}=3.87, \mathrm{p}=0.02\right)($ Figure 7$)$.

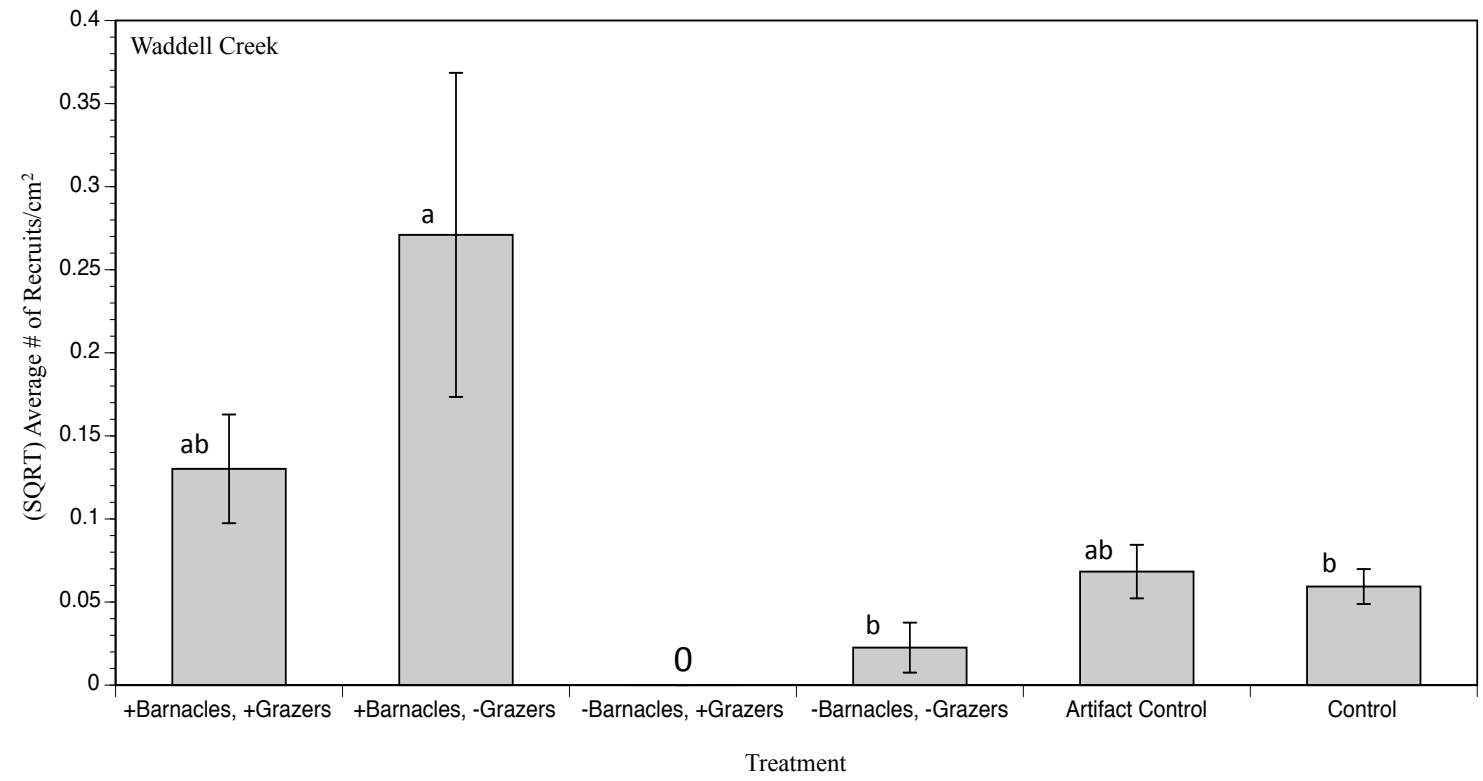

Figure 7. Bar graph of \# of Pelvetiopsis limitata recruits $/ \mathrm{cm}^{2}$ averaged across each treatment and square root transformed. Means that share letters are not significantly different. Error bars are standard error.

Multiple comparisons (Tukey's HSD) showed significant differences between treatments 2 (+barnacles, -grazers) and 4 (-barnacles, -grazers) $(\mathrm{p}=0.02)$ (Figure 7, Table 
4). Recruitment was significantly higher in the absence of grazers when barnacles were present.

Table 4. Multiple Comparisons (Tukey's HSD) of treatment effects at Waddell Creek.

\begin{tabular}{|c|c|c|c|}
\hline Treatment I & Treatment $\mathbf{J}$ & Mean Difference (I-J) & $\mathbf{P}$ \\
\hline \multirow{4}{*}{$\begin{array}{c}1 \\
+ \text { Barnacles, }+ \text { Grazers }\end{array}$} & 2 & -0.14 & 0.2 \\
\hline & 4 & 0.108 & 0.5 \\
\hline & 5 & 0.062 & 0.9 \\
\hline & 6 & 0.071 & 0.8 \\
\hline \multirow{4}{*}{$\begin{array}{c}2 \\
+ \text { +Barnacles, -Grazers }\end{array}$} & 1 & 0.141 & 0.2 \\
\hline & 4 & 0.248 & 0.02 \\
\hline & 5 & 0.203 & 0.1 \\
\hline & 6 & 0.212 & 0.05 \\
\hline \multirow{4}{*}{$\begin{array}{c}4 \\
\text {-Barnacles, -Grazers }\end{array}$} & 1 & -0.108 & 0.5 \\
\hline & 2 & -0.248 & 0.02 \\
\hline & 5 & -0.046 & 0.9 \\
\hline & 6 & -0.037 & 0.9 \\
\hline \multirow{4}{*}{$\begin{array}{c}5 \\
\text { Artifact control }\end{array}$} & 1 & -0.062 & 0.9 \\
\hline & 2 & -0.203 & 0.1 \\
\hline & 4 & 0.046 & 0.9 \\
\hline & 6 & 0.009 & 1 \\
\hline \multirow{4}{*}{$\begin{array}{c}6 \\
\text { Unmanipulated Control }\end{array}$} & 1 & -0.071 & 0.8 \\
\hline & 2 & -0.212 & 0.05 \\
\hline & 4 & 0.037 & 0.9 \\
\hline & 5 & -0.009 & 1 \\
\hline
\end{tabular}

The highest recruitment $/ \mathrm{cm}^{2}$ at this site across treatments was observed on barnacle tests $(\bar{x}=0.269 \pm 0.049)$ and little to no recruitment $/ \mathrm{cm}^{2}$ was observed on bare rock $(\bar{x}=0.007 \pm 0.004)$ (Figure 8$)$. Raw recruitment numbers on both barnacle and rock in each treatment are depicted in Table 5. A two-sample t-test showed that recruitment on barnacles was significantly higher than on rock $\left(\mathrm{t}_{44}=6.66, \mathrm{p}<0.0001\right)$. 


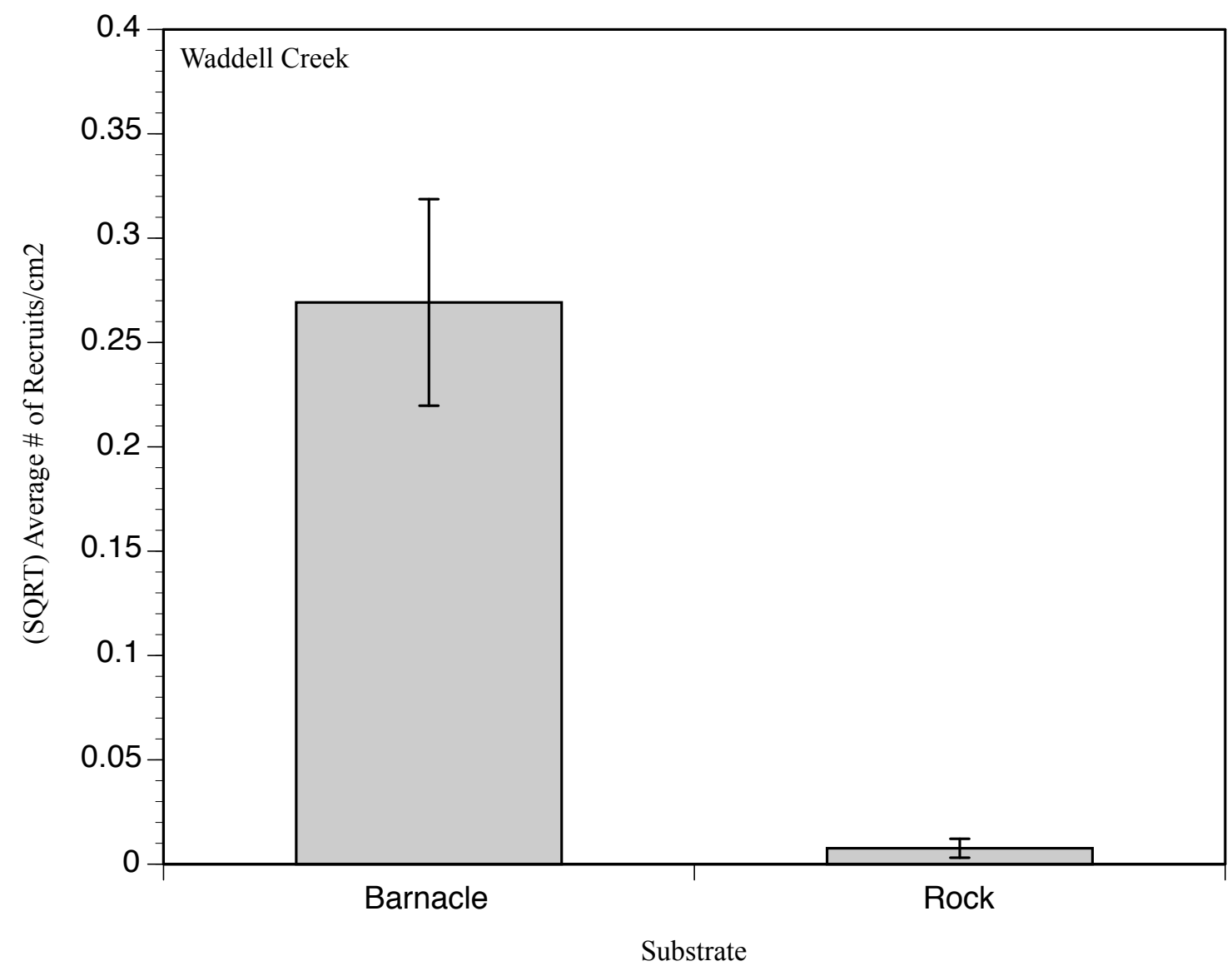

Figure 8. Average Pelvetiopsis limitata recruits $/ \mathrm{cm}^{2}$ across all treatments on barnacle and rock at the time of peak recruitment at Waddell Creek in April 2014. Average \# of recruits $/ \mathrm{cm}^{2}$ on barnacles was $0.269 \pm 0.04$. Average $\#$ of recruits $/ \mathrm{cm}^{2}$ on rock was $0.0008 \pm 0.0006$. Error bars are standard error. 
Table 5. Number of Pelvetiopsis limitata recruits in each treatment and average recruitment within each treatment on barnacle and rock.

\begin{tabular}{|c|c|c|c|c|c|}
\hline Treatment & Block & $\begin{array}{c}\text { \# of Recruits } \\
\text { on Barnacle }\end{array}$ & Mean $\pm \mathrm{SE}$ & $\begin{array}{c}\text { \# of Recruits } \\
\text { on Rock }\end{array}$ & Mean $\pm \mathrm{SE}$ \\
\hline \multirow{5}{*}{$\begin{array}{c}1 \\
+ \text { Barnacles, }+ \text { Grazers }\end{array}$} & 1 & 32 & & 0 & \\
\hline & 2 & 6 & & 0 & \\
\hline & 3 & 1 & & 0 & \\
\hline & 4 & 27 & & 0 & \\
\hline & 5 & 9 & $15 \pm 6.11$ & 0 & $0 \pm 0$ \\
\hline \multirow{5}{*}{$\begin{array}{c}2 \\
+ \text { +Barnacles, -Grazers }\end{array}$} & 1 & 4 & & 0 & \\
\hline & 2 & 21 & & 0 & \\
\hline & 3 & 14 & & 0 & \\
\hline & 4 & 85 & & 2 & \\
\hline & 5 & 268 & $78.4 \pm 49.48$ & 0 & $0.4 \pm 0.4$ \\
\hline \multirow{5}{*}{$\begin{array}{c}3 \\
\text {-Barnacles, }+ \text { Grazers }\end{array}$} & 1 & $*$ & & 0 & \\
\hline & 2 & $*$ & & 0 & \\
\hline & 3 & $*$ & & 0 & \\
\hline & 4 & $*$ & & 0 & \\
\hline & 5 & $*$ & $*$ & 0 & $0 \pm 0$ \\
\hline \multirow{5}{*}{$\begin{array}{c}4 \\
\text {-Barnacles, -Grazers }\end{array}$} & 1 & $*$ & & 0 & \\
\hline & 2 & $*$ & & 0 & \\
\hline & 3 & $*$ & & 1 & \\
\hline & 4 & $*$ & & 0 & \\
\hline & 5 & $*$ & $*$ & 4 & $1 \pm 0.77$ \\
\hline \multirow{5}{*}{$\begin{array}{c}5 \\
\text { Artifact Control }\end{array}$} & 1 & 1 & & 0 & \\
\hline & 2 & 2 & & 0 & \\
\hline & 3 & $\mathrm{~N} / \mathrm{D}$ & & 0 & \\
\hline & 4 & 1 & & 0 & \\
\hline & 5 & $\mathrm{~N} / \mathrm{D}$ & $1.33 \pm 0.33$ & 0 & $0 \pm 0$ \\
\hline \multirow{5}{*}{$\begin{array}{c}6 \\
\text { Unmanipulated } \\
\text { Control }\end{array}$} & 1 & 4 & & 0 & \\
\hline & 2 & 6 & & 0 & \\
\hline & 3 & 1 & & 0 & \\
\hline & 4 & 5 & & 0 & \\
\hline & 5 & 5 & $4.2 \pm 0.86$ & 0 & $0 \pm 0$ \\
\hline
\end{tabular}

*Treatments that exclude barnacles. 


\section{Soberanes Point}

At Soberanes Point, the highest recruitment at each time point was observed in plots where grazers were present, and little to no recruitment was observed in plots where grazers were absent regardless of the presence or absence of barnacles (Figure 9).

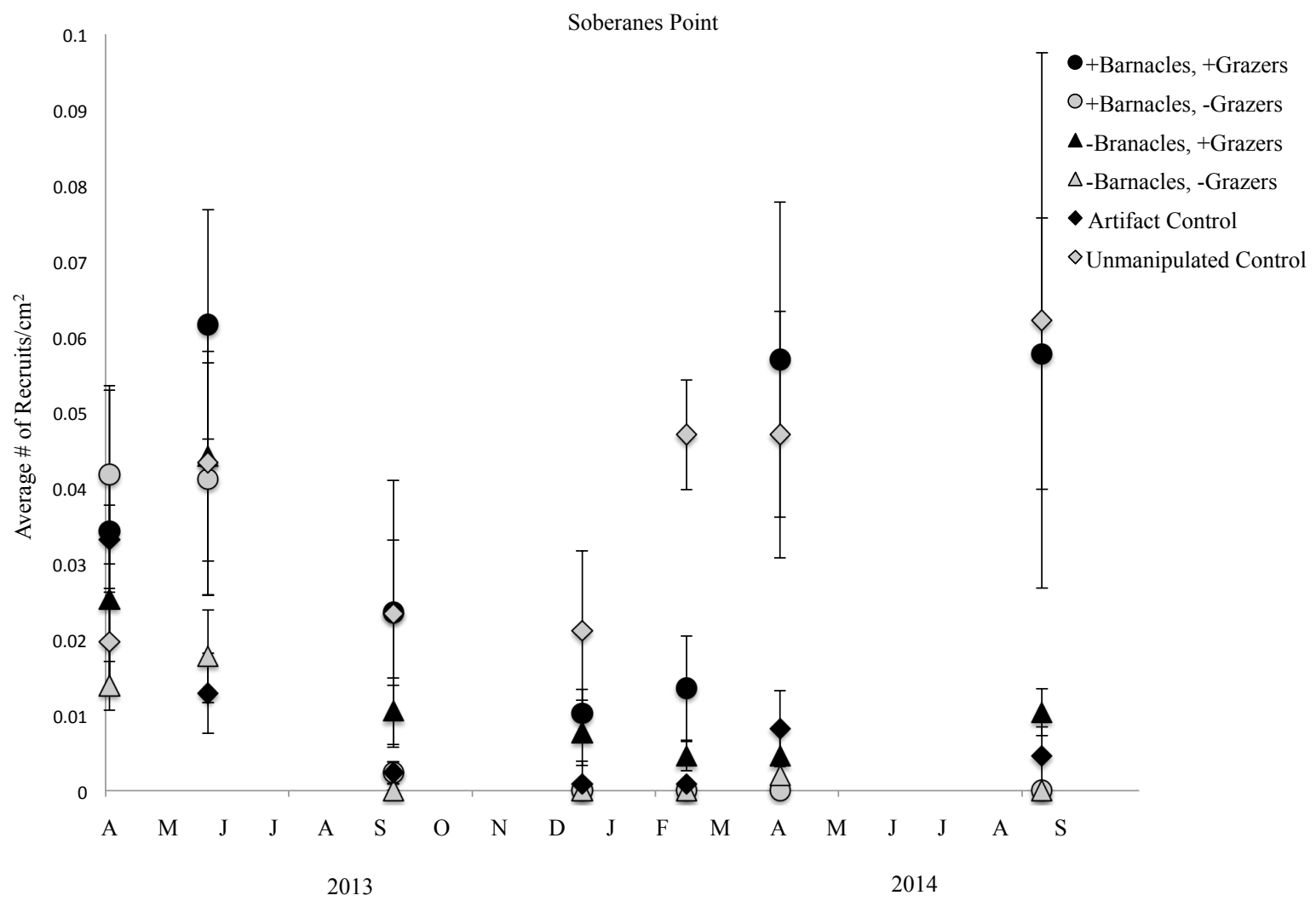

Figure 9. Pelvetiopsis limitata recruitment from April 2013-September 2014 at Soberanes Point. Peak recruitment events were observed in May 2013 and April 2014. Each point is the average \# of recruits $/ \mathrm{cm}^{2}$ across 5 treatments and error bars are standard error.

At the time of peak recruitment at Soberanes Point, recruits were observed in all treatments (Table 6). 
Table 6. Number of Pelvetiopsis limitata recruits in each treatment at the peak time of recruitment in April 2014 at Soberanes Point.

\begin{tabular}{|c|c|c|c|}
\hline Treatment & Block & \# of Recruits & Mean \pm SE \\
\hline \multirow{5}{*}{$\begin{array}{c}1 \\
+ \text { Barnacles, }+ \text { Grazers }\end{array}$} & 1 & 19 & \\
\hline & 2 & 50 & \\
\hline & 3 & 79 & \\
\hline & 4 & 10 & \\
\hline & 5 & 17 & $35 \pm 12.97$ \\
\hline \multirow{5}{*}{$\begin{array}{c}2 \\
\text { +Barnacles, -Grazers }\end{array}$} & 1 & 0 & \\
\hline & 2 & 1 & \\
\hline & 3 & 0 & \\
\hline & 4 & 0 & \\
\hline & 5 & 0 & $0.2 \pm 0.2$ \\
\hline \multirow{5}{*}{$\begin{array}{c}3 \\
\text {-Barnacles, +Grazers }\end{array}$} & 1 & 12 & \\
\hline & 2 & 19 & \\
\hline & 3 & 8 & \\
\hline & 4 & 10 & \\
\hline & 5 & 3 & $10.4 \pm 2.62$ \\
\hline \multirow{5}{*}{$\begin{array}{c}4 \\
\text {-Barnacles, -Grazers }\end{array}$} & 1 & 0 & \\
\hline & 2 & 0 & \\
\hline & 3 & 0 & \\
\hline & 4 & 0 & \\
\hline & 5 & 7 & $1.4 \pm 1.4$ \\
\hline \multirow{5}{*}{$\begin{array}{c}5 \\
\text { Artifact Control }\end{array}$} & 1 & 18 & \\
\hline & 2 & 1 & \\
\hline & 3 & 3 & \\
\hline & 4 & 5 & \\
\hline & 5 & 0 & $5.4 \pm 3.26$ \\
\hline \multirow{5}{*}{$\begin{array}{c}6 \\
\text { Unmanipulated Control }\end{array}$} & 1 & 9 & \\
\hline & 2 & 13 & \\
\hline & 3 & 2 & \\
\hline & 4 & 41 & \\
\hline & 5 & 10 & $15 \pm 6.75$ \\
\hline
\end{tabular}


A randomized blocked ANOVA was not significant $(\mathrm{p}=0.9)$. No interaction between block and treatment is assumed in randomized block analysis, so there was no interaction term. A one-way ANOVA testing the main effects of treatment on P. limitata recruitment was significant $\left(\mathrm{F}_{5,24}=8.64, \mathrm{p}<0.0001\right)$ (Figure 10).

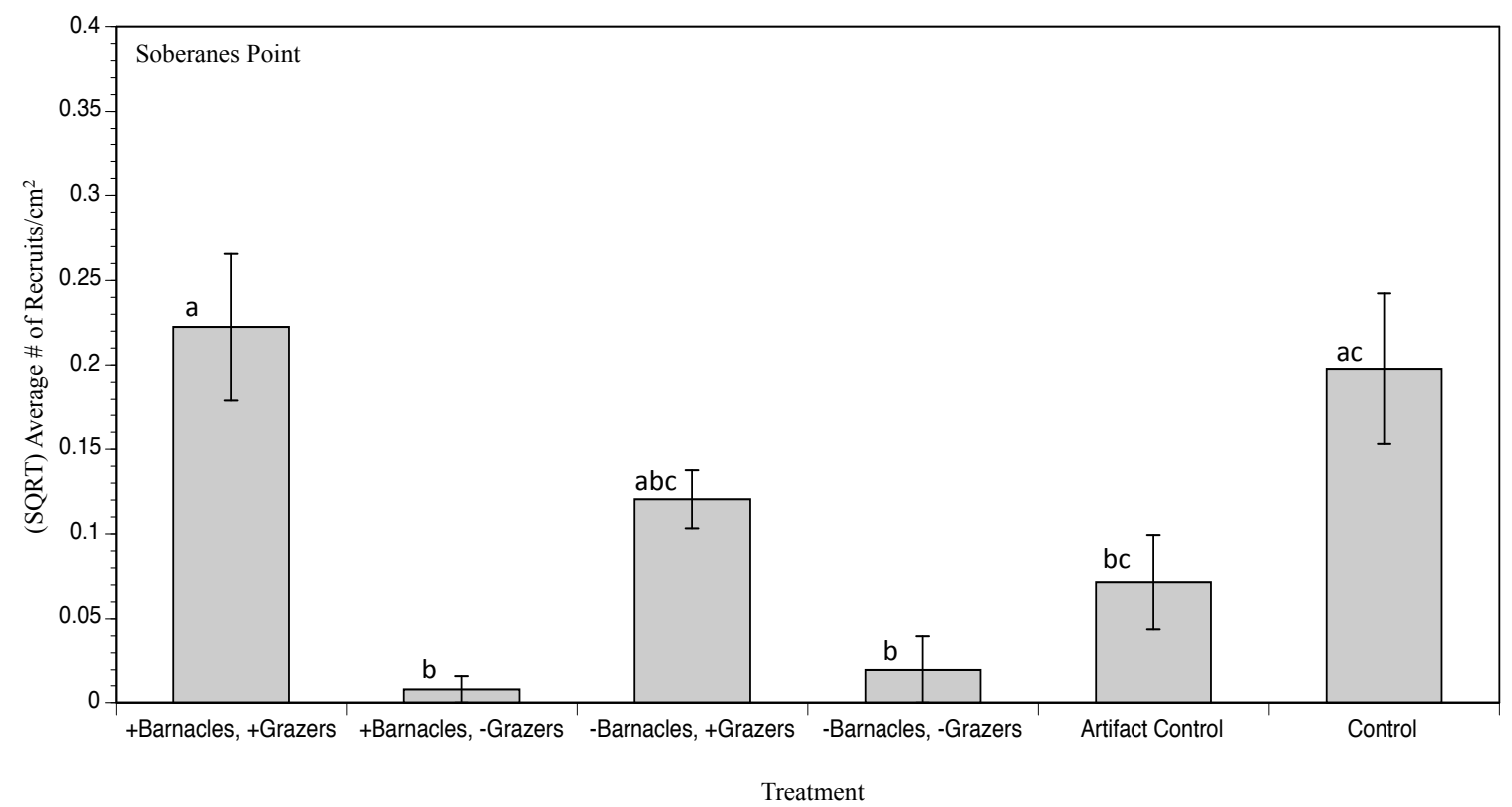

Figure 10. Bar graph of \# of Pelvetiopsis limitata recruits $/ \mathrm{cm}^{2}$ averaged across each treatment and square root transformed. Means that share letters are not significantly different. Error bars are standard error.

A multiple comparison test (Tukey's HSD) revealed that treatment 1 (+barnacles, +grazers) was significantly different than treatments 2 (+barnacles, -grazers) $(\mathrm{p}<0.0001$, 4 (- barnacles, -grazers) $(\mathrm{p}<0.0001)$, and 5 (artifact control) $(\mathrm{p}=0.01)$ (Figure 10, Table 7). Comparisons between all other treatments were not significant. Overall, recruitment was significantly higher in plots where grazers were present. 
Table 7. Multiple Comparisons (Tukey's HSD) of treatment effects at Soberanes Point.

\begin{tabular}{|c|c|c|c|}
\hline Treatment I & Treatment $\mathbf{J}$ & Mean Difference (I-J) & $\mathbf{P}$ \\
\hline \multirow{5}{*}{$\begin{array}{c}1 \\
+ \text { Barnacles, }+ \text { Grazers }\end{array}$} & 2 & 0.2 & $<0.0001$ \\
\hline & 3 & 0.091 & 0.164 \\
\hline & 4 & 0.188 & $<0.0001$ \\
\hline & 5 & 0.138 & 0.01 \\
\hline & 6 & 0.075 & 0.3 \\
\hline \multirow{5}{*}{$\begin{array}{c}2 \\
\text { +Barnacles, -Grazers }\end{array}$} & 1 & -0.2 & $<0.0001$ \\
\hline & 3 & -0.109 & 0.06 \\
\hline & 4 & -0.012 & 0.9 \\
\hline & 5 & -0.062 & 0.5 \\
\hline & 6 & -0.125 & 0.02 \\
\hline \multirow{5}{*}{$\begin{array}{c}3 \\
\text {-Barnacles, +Grazers }\end{array}$} & 1 & -0.091 & 0.1 \\
\hline & 2 & 0.109 & 0.06 \\
\hline & 4 & 0.097 & 0.1 \\
\hline & 5 & 0.048 & 0.7 \\
\hline & 6 & -0.015 & 0.9 \\
\hline \multirow{5}{*}{$\begin{array}{c}4 \\
\text {-Barnacles, -Grazers }\end{array}$} & 1 & -0.188 & $<0.0001$ \\
\hline & 2 & 0.012 & 0.9 \\
\hline & 3 & -0.097 & 0.1 \\
\hline & 5 & -0.049 & 0.7 \\
\hline & 6 & -0.112 & 0.05 \\
\hline \multirow{5}{*}{$\begin{array}{c}5 \\
\text { Artifact Control }\end{array}$} & 1 & -0.138 & 0.01 \\
\hline & 2 & 0.062 & 0.5 \\
\hline & 3 & -0.048 & 0.7 \\
\hline & 4 & 0.049 & 0.7 \\
\hline & 6 & -0.063 & 0.5 \\
\hline \multirow{5}{*}{$\begin{array}{c}6 \\
\text { Unmanipulated Control }\end{array}$} & 1 & 0.075 & 0.3 \\
\hline & 2 & 0.124 & 0.02 \\
\hline & 3 & 0.015 & 0.9 \\
\hline & 4 & 0.112 & 0.05 \\
\hline & 5 & 0.063 & 0.5 \\
\hline
\end{tabular}


Recruitment across treatments at this site was observed on both barnacle $(\bar{x}=0.03 \pm 0.014)$ and rock, but was higher on rock overall $(\bar{x}=0.08 \pm 0.018)$ (Figure 11).

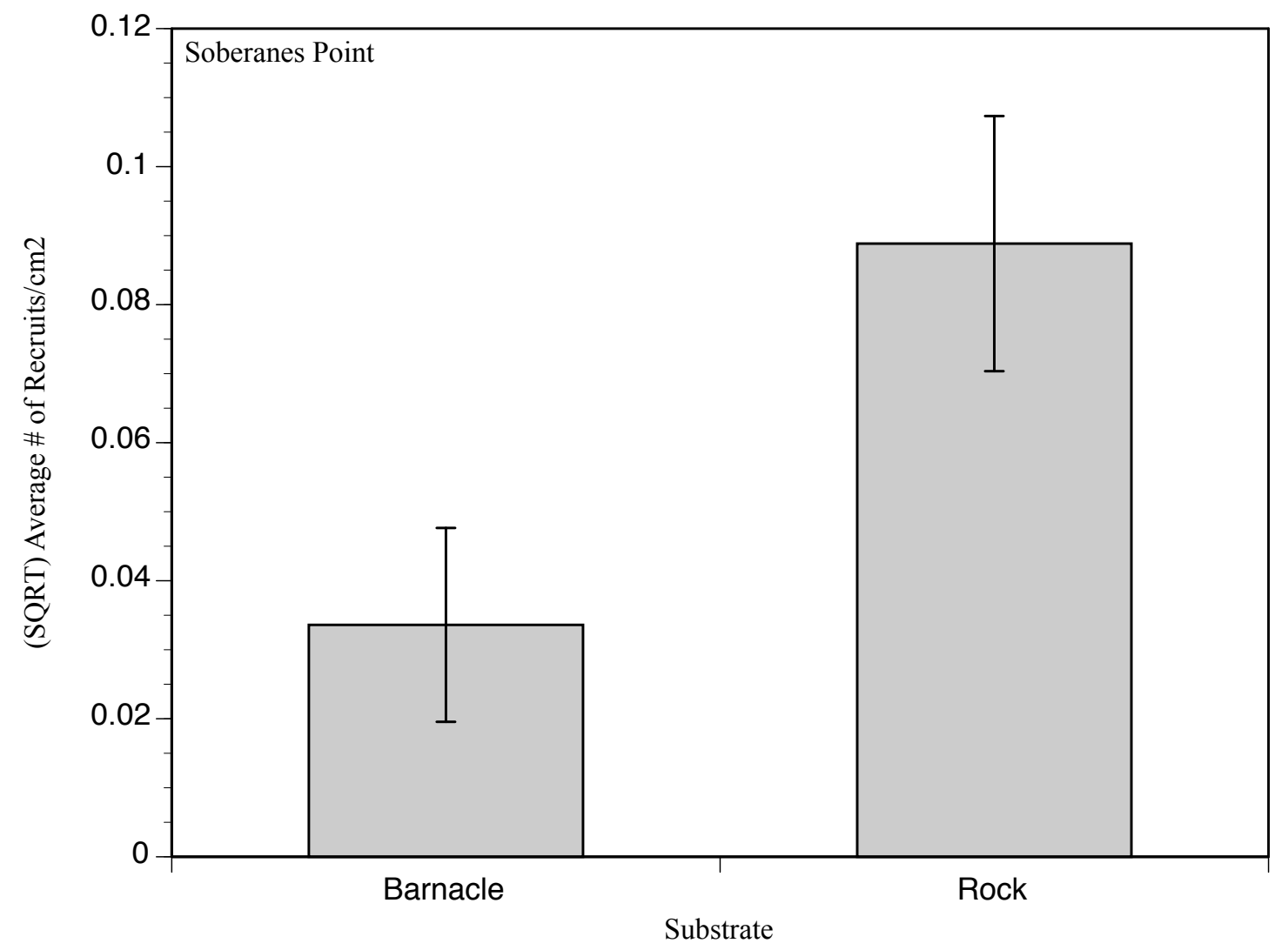

Figure 11. Average Pelvetiopsis limitata recruits $/ \mathrm{cm}^{2}$ across all treatments on barnacle and rock at Soberanes Point at the time of peak recruitment in April 2014. Average \# of recruits $/ \mathrm{cm}^{2}$ on barnacle was $0.03 \pm 0.014$. Average \# of recruits $/ \mathrm{cm}^{2}$ on rock was $0.08 \pm 0.018$. Error bars are standard error.

Raw recruitment numbers on both barnacle and rock in each treatment are depicted in Table 8. A two-sample t-test showed that recruitment on rock was significantly higher than on barnacles $\left(\mathrm{t}_{48}=-2.17, \mathrm{p}=0.03\right)$. 
Table 8. Number of Pelvetiopsis limitata recruits in each treatment and average recruitment across each treatment on barnacle and rock.

\begin{tabular}{|c|c|c|c|c|c|}
\hline Treatment & Block & $\begin{array}{c}\text { \# of Recruits } \\
\text { on Barnacle }\end{array}$ & Mean \pm SE & $\begin{array}{l}\text { \# of Recruits } \\
\text { on Rock }\end{array}$ & Mean $\pm \mathrm{SE}$ \\
\hline \multirow{5}{*}{$\begin{array}{c}1 \\
+ \text { Barnacles, },+ \text { Grazers }\end{array}$} & 1 & 5 & & 14 & \\
\hline & 2 & 3 & & 47 & \\
\hline & 3 & 35 & & 44 & \\
\hline & 4 & 8 & & 2 & \\
\hline & 5 & 10 & $12 \pm 5.83$ & 7 & $22.8 \pm 9.47$ \\
\hline \multirow{5}{*}{$\begin{array}{c}2 \\
+ \text { +Barnacles, -Grazers }\end{array}$} & 1 & 0 & & 0 & \\
\hline & 2 & 1 & & 0 & \\
\hline & 3 & 0 & & 0 & \\
\hline & 4 & 0 & & 0 & \\
\hline & 5 & 0 & $0.2 \pm 0.2$ & 0 & $0 \pm 0$ \\
\hline \multirow{5}{*}{$\begin{array}{c}3 \\
\text {-Barnacles, +Grazers }\end{array}$} & 1 & $*$ & & 12 & \\
\hline & 2 & $*$ & & 19 & \\
\hline & 3 & $*$ & & 8 & \\
\hline & 4 & $*$ & & 10 & \\
\hline & 5 & $*$ & $*$ & 3 & $10.4 \pm 2.62$ \\
\hline \multirow{5}{*}{$\begin{array}{c}4 \\
\text {-Barnacles, -Grazers }\end{array}$} & 1 & $*$ & & 0 & \\
\hline & 2 & $*$ & & 0 & \\
\hline & 3 & $*$ & & 0 & \\
\hline & 4 & $*$ & & 0 & \\
\hline & 5 & $*$ & $*$ & 4 & $0.8 \pm 0.8$ \\
\hline \multirow{5}{*}{$\begin{array}{c}5 \\
\text { Artufact Control }\end{array}$} & 1 & 0 & & 0 & \\
\hline & 2 & 0 & & 0 & \\
\hline & 3 & 0 & & 0 & \\
\hline & 4 & 0 & & 0 & \\
\hline & 5 & 0 & $3 \pm 2.51$ & 0 & $0 \pm 0$ \\
\hline \multirow{5}{*}{$\begin{array}{c}6 \\
\text { Control }\end{array}$} & 1 & 3 & & 13 & \\
\hline & 2 & 13 & & 0 & \\
\hline & 3 & 2 & & 1 & \\
\hline & 4 & 37 & & 1 & \\
\hline & 5 & 9 & $12.8 \pm 6.37$ & 0 & $0 \pm 0$ \\
\hline
\end{tabular}

*Treatments that exclude barnacles. 


\section{Grazer Density, Species Assemblages, and Size Classes}

Average limpet densities over time were higher at Soberanes Point than Waddell Creek (Figure 12). Overall, limpet densities were higher in plots where barnacles were present at Waddell Creek, and higher in treatments where barnacles were absent at Soberanes Point.

Species assemblages between sites also differed (Table 9). The dominant species at Waddell Creek was Lottia paradigitalis where 96 individuals were observed across treatments at the end of the experiment. Lottia scabra was the dominant species at Soberanes Point where 265 individuals were observed across treatments.

Table 9. Limpet species assemblages and size classes at Waddell Creek and Soberanes Point counted and identified at the end of the experiment. Medium sized limpets of all observed species (5-15mm) dominated at both sites.

Waddell Creek

\begin{tabular}{|l|c|c|c|c|}
\hline \multicolumn{1}{|c|}{ Species } & $\begin{array}{c}\text { Small } \\
(<5 \mathrm{~mm})\end{array}$ & $\begin{array}{c}\text { Medium } \\
(5-15 \mathrm{~mm})\end{array}$ & $\begin{array}{c}\text { Large } \\
(>15 \mathrm{~mm})\end{array}$ & Total \\
\hline Lottia digitalis/austrodigitalis & 3 & 63 & 5 & 71 \\
\hline Lottia paradigitalis & 14 & 82 & 0 & 96 \\
\hline Lottia scabra & 6 & 25 & 0 & 31 \\
\hline Lottia pelta & 1 & 1 & 1 & 3 \\
\hline
\end{tabular}

Soberanes Point

\begin{tabular}{|l|c|c|c|c|}
\hline \multicolumn{1}{|c|}{ Species } & $\begin{array}{c}\text { Small } \\
(<5 \mathrm{~mm})\end{array}$ & $\begin{array}{c}\text { Medium } \\
(5-15 \mathrm{~mm})\end{array}$ & $\begin{array}{c}\text { Large } \\
(>15 \mathrm{~mm})\end{array}$ & Total \\
\hline Lottia digitalis/austrodigitalis & 4 & 201 & 0 & 205 \\
\hline Lottia paradigitalis & 3 & 2 & 0 & 5 \\
\hline Lottia scabra & 52 & 205 & 8 & 265 \\
\hline Lottia pelta & 0 & 1 & 0 & 1 \\
\hline
\end{tabular}




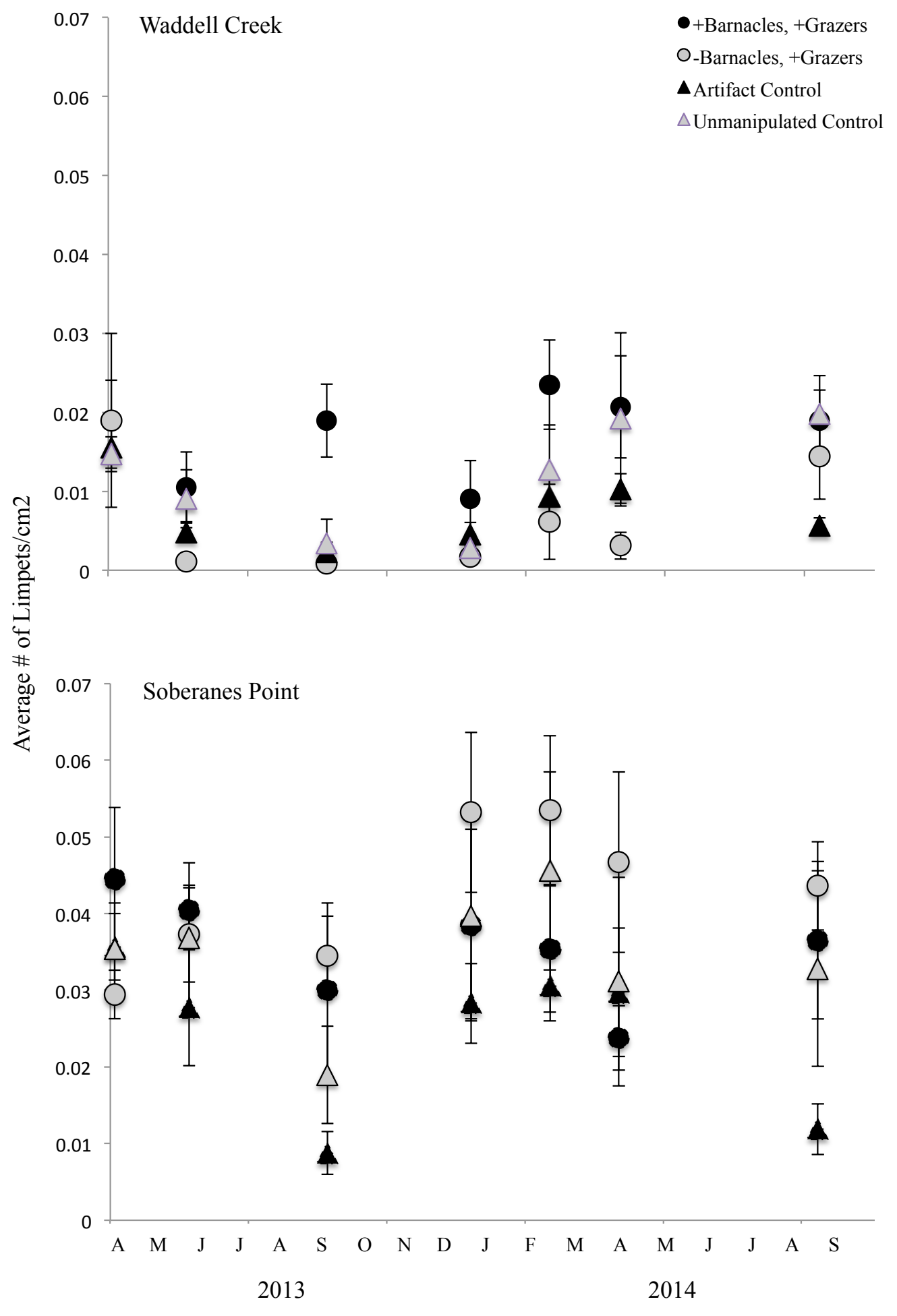

Figure 12. Average limpet densities over time at Waddell Creek and Soberanes Point. Each point is the average \# of limpets $/ \mathrm{cm}^{2}$ across 5 treatments. Error bars are standard error. 
The results of two-sample t-tests testing differences in individual species densities between sites (Figure 13) are as follows: Lottia digitalis/austrodigitalis densities were significantly higher at Soberanes Point $\left(\mathrm{t}_{28}=2.74, \mathrm{p}=0.009\right)$, L. paradigitalis densities were significantly higher at Waddell Creek $\left(\mathrm{t}_{28}=-3.16, \mathrm{p}=0.003\right)$, L. scabra densities were significantly higher at Soberanes Point $\left(\mathrm{t}_{28}=5.94, \mathrm{p}<0.0001\right)$, and L. pelta densities were not significantly different between sites $\left(\mathrm{t}_{28}=-0.874, \mathrm{p}=0.44\right)$.

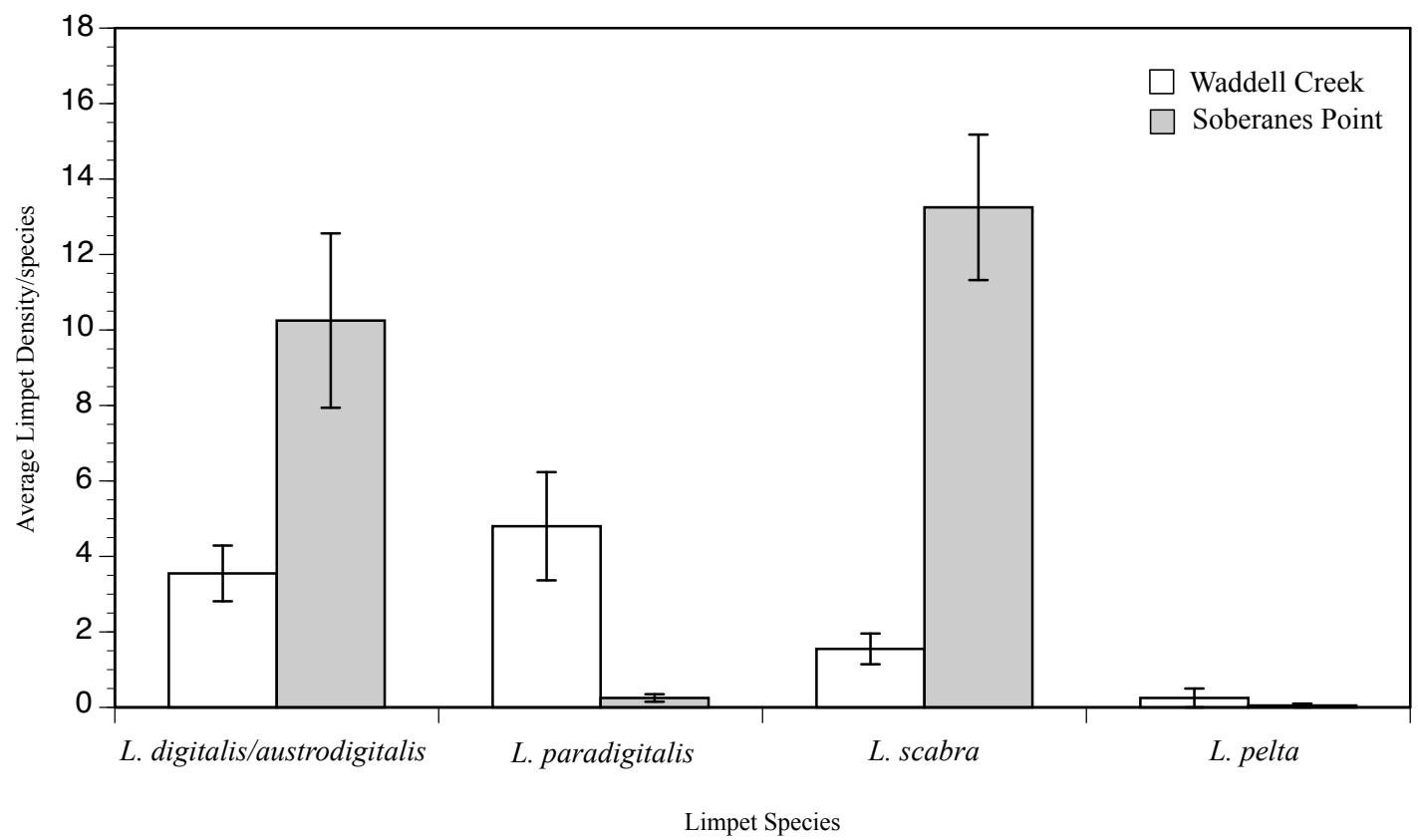

Figure 13. Average limpet densities in all treatments of each species at Waddell Creek and Soberanes Point. Counts were taken at the end of the experiment. Error bars are standard error.

Two-sample t-tests testing the differences between size classes at both sites were as follows (Figure 14): density of small $(<5 \mathrm{~mm})$ limpets between sites was not significantly different $\left(\mathrm{t}_{158}=1.68, \mathrm{p}=0.093\right)$, density of medium $(5-15 \mathrm{~mm})$ limpets was significantly 
higher at Soberanes Point $\left(\mathrm{t}_{158}=3.05, \mathrm{p}=0.003\right)$, and density of large $(>15 \mathrm{~mm})$ limpets between sites was not significantly different $\left(\mathrm{t}_{158}=0.384, \mathrm{p}=0.701\right)$.

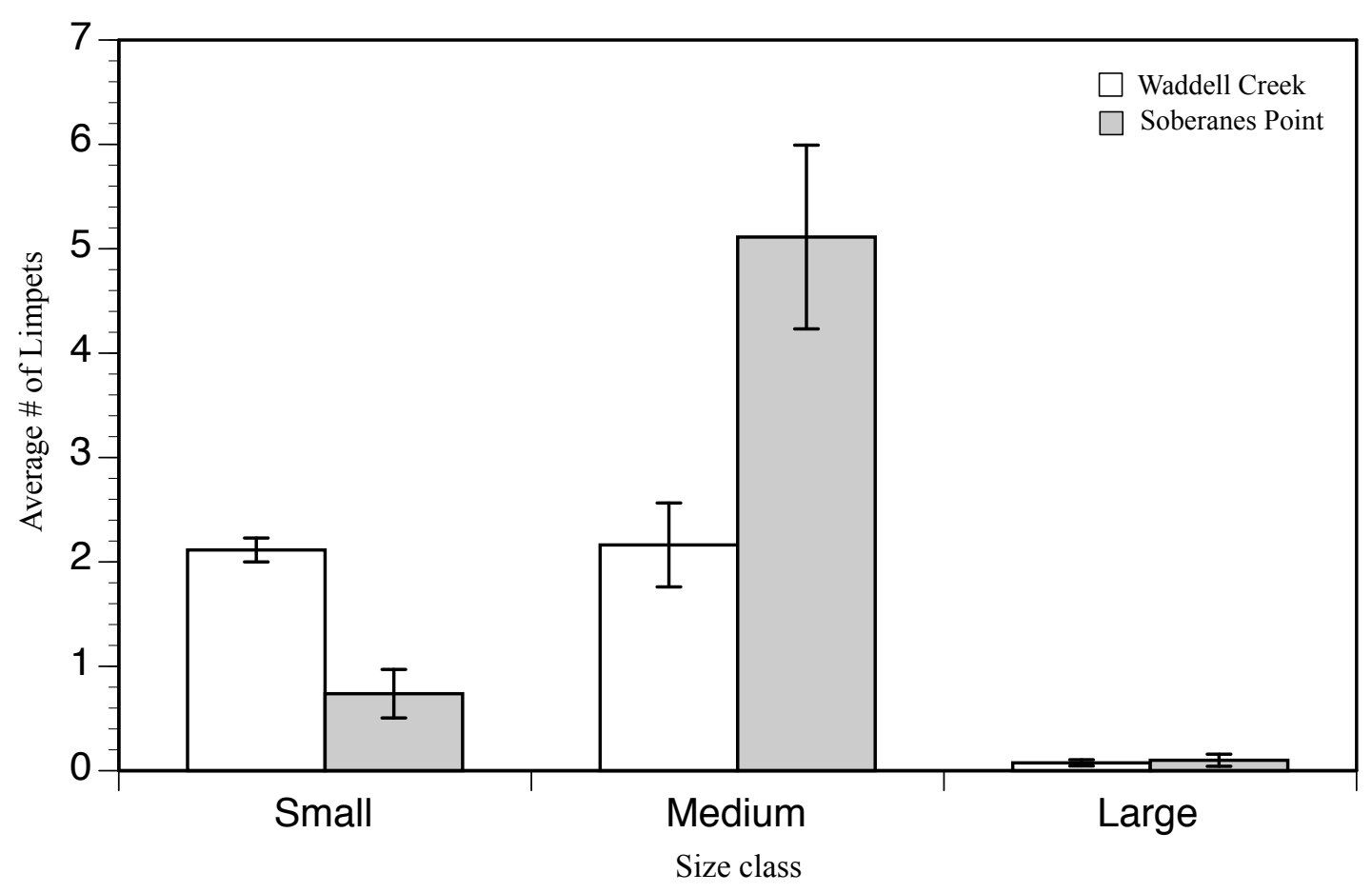

Figure 14. Average \# of limpets separated by size class in all treatments at Waddell Creek and Soberanes Point. Error bars are standard error. 


\section{Humidity Measurements}

Because of the significant effect of the artifact control on Pelvetiopsis limitata recruitment at Soberanes Point, further examination of possible factors, such as humidity levels, contributing to this effect were tested. Randomized block ANOVAs tested for the effects of treatment and any variation in response between blocks on relative humidity (Figure 15).

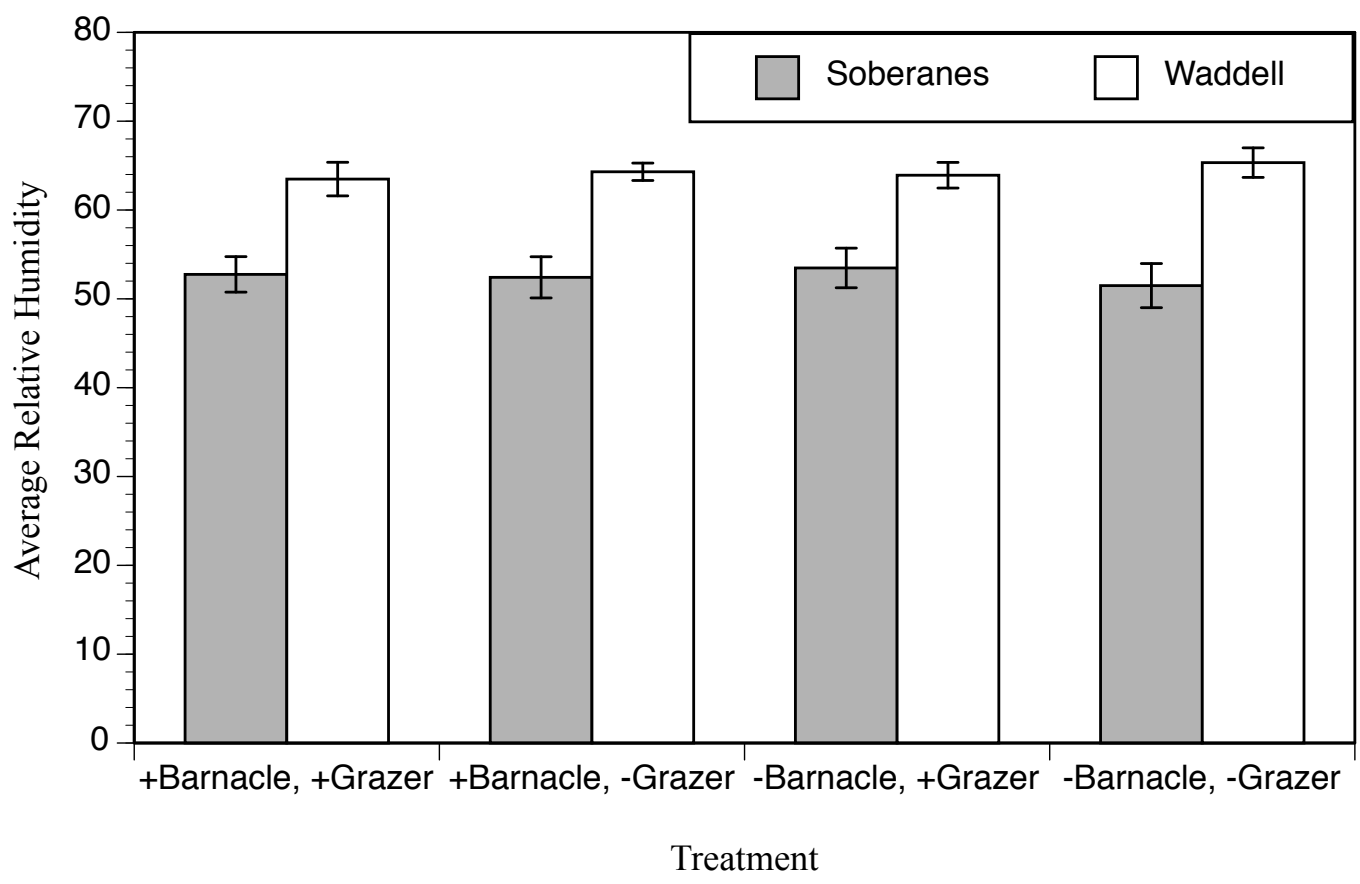

Figure 15. Average relative humidity per plot at Waddell Creek and Soberanes Point. Error bars are standard error.

Block had a significant effect on humidity levels at both sites: Soberanes Point: $\mathrm{F}_{4,12}=34.59, \mathrm{p}<0.0001$ and Waddell Creek: $\mathrm{F}_{4,12}=10.51, \mathrm{p}=0.001$. Treatment had no significant effect on humidity at both sites (Soberanes Point: $F_{3,12}=1.25$, $p=0.34$; Waddell Creek: $\left.\mathrm{F}_{3,12}=0.57, \mathrm{p}=0.74\right)$. 


\section{Discussion}

Studies focused on defining rocky intertidal species interaction webs have provided insight into the structure and functionality of many ecological communities, both marine and terrestrial (Connell \& Slatyer, 1977; Hacker \& Gaines, 1997; Maggi, Bertocci, Vaselli, \& Benedetti-Cecchi, 2011; R.T. Paine, 1977). In a 1971 study on competition and space partitioning in the rocky intertidal, Dayton defined a number of paradigms for the ecological interactions occurring in this system. Dayton's (1971) study inspired others to further explore the complicated interactions occurring between intertidal organisms, and how these interactions drive succession, recovery following a disturbance, and community structure. Dayton (1971) concluded that competition between species for space and other resources was thought to be the main driver behind many interactions between organisms, but studies that followed began to explore positive interactions and facilitation as important drivers shaping interaction webs (Bertness \& Callaway, 1994; Bruno et al., 2003; Bulleri, 2009; Jernakoff, 1983; Kim, 1997; Lubchenco, 1983; Stachowicz, 2001). The interaction web guiding my research (Figure 16a) was a product of the combined results from these studies, and defined the interactions thought to occur between barnacles, macroalgae (usually a fucoid), and invertebrate grazers in the high intertidal.

Although what seems like an exhaustive collection of literature exists on this interaction web, little research has been done on how these webs shift due to geographic location or variation in exposure to physical factors. This study aimed to provide novel insights about a commonly studied interaction web in the high intertidal in central 
California, and how this web responds to changes in the physical environment, primarily variation in the underlying rock type.

Past studies on the barnacle assemblage were primarily conducted on smooth substrates, polished and worn away by glacial activity (Dayton, 1971; Jernakoff, 1985; Kim, 1997) or sedimentary in nature such as sandstone (Dungan, 1986; Lubchenco, 1983). Santa Cruz Mudstone, a relatively smooth, marine bedded sedimentary rock, is the dominant substrate type in the rocky intertidal at Waddell Creek in the northern part of the Monterey Bay region, so Waddell Creek was chosen as a study site to confirm the paradigm in central California. Experimentally altering the presence and absence of both barnacles and grazers in study plots helped reveal what roles these species played in Pelvetiopsis limitata colonization in the high intertidal, and a site-specific interaction web was created (Figure 16b). Recruitment occurred almost exclusively in plots where barnacles were present, regardless of the presence or absence of grazers, which suggests that barnacles are a driving factor in recruitment of $P$. limitata at Waddell Creek and that limpet grazers have little to no effect. Results of a one-way ANOVA testing the effects of experimental manipulations on $P$. limitata recruitment were significant, and multiple comparisons that tested differences between individual treatments further support this conclusion, as treatments that excluded limpet grazers (treatments 2 and 4) were significantly different from one another (Table 4). Recruitment in treatment 2 (+barnacles, -grazers) was significantly higher than recruitment in treatment 4 (barnacles, -grazers). The primary difference between these plots was the presence or absence of barnacles. If interactions between $P$. limitata recruits and limpet grazers at 
Waddell Creek mirrored the current paradigm, recruitment should have occurred in both treatments that excluded grazers, and this was not observed at this site.

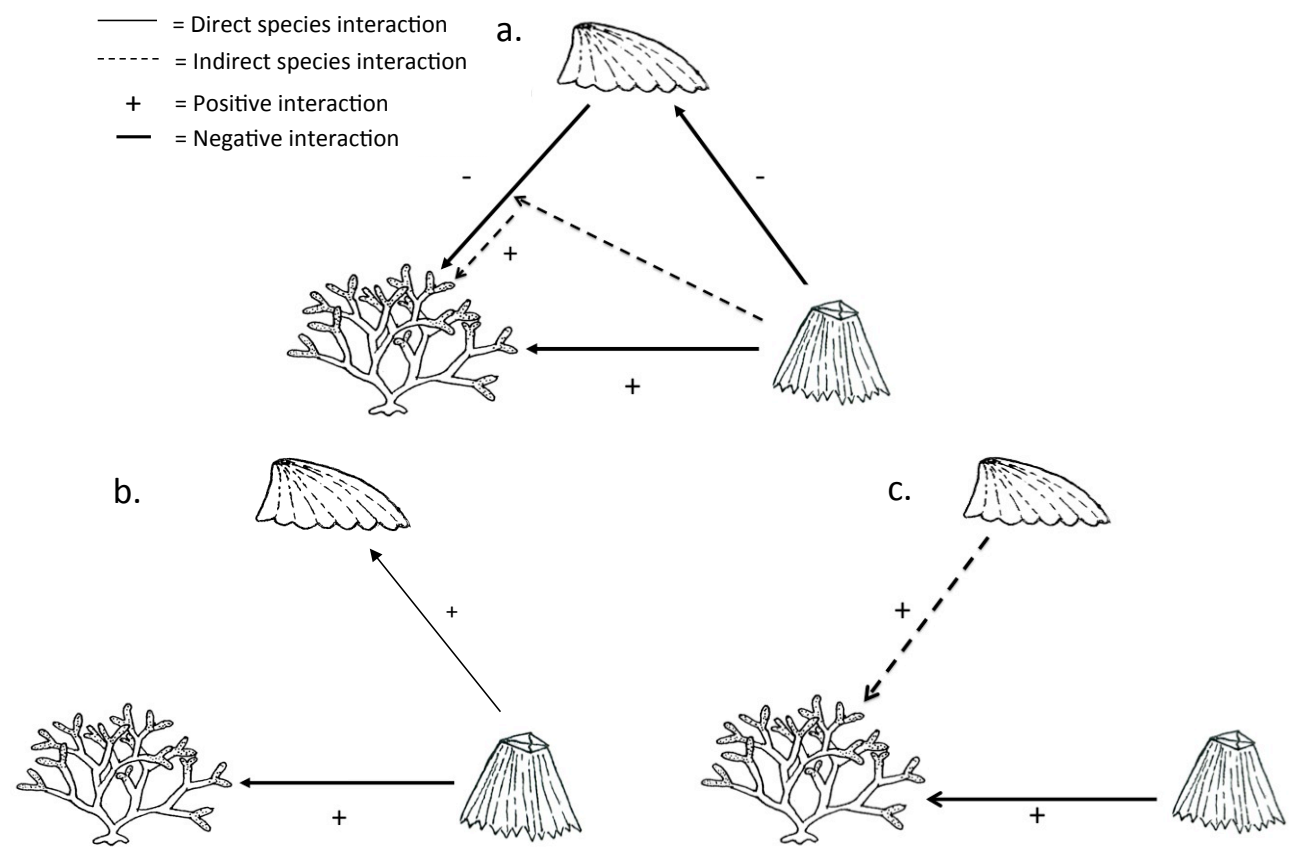

Figure 16. Species interactions webs that depict interaction webs for a) the current paradigm and interactions that occurred at b) Waddell Creek and c) Soberanes Point. Lottia spp. is pictured at the top, Pelvetiopsis limitata is pictured in the bottom left, and Balanus glandula is pictured in the bottom right in each web. Each arrow represents a single interaction, and points towards the species affected by that interaction.

A clear pattern that further supports the conclusion that the presence of barnacles is likely driving the recruitment of $P$. limitata at Waddell Creek emerges when the raw data are examined. Not only did the highest recruitment occur in plots where barnacles were present regardless of the presence or absence of limpet grazers, but $P$. limitata 
recruits were almost always observed attached directly to barnacle tests. This suggests a direct, positive interaction exists between the barnacle, $B$. glandula and juvenile $P$. limitata, and that grazers do not appear to have an effect on P. limitata recruitment, suggesting no interaction occurs between these species at this site (Figure 16b). Again, this does not adhere to the current paradigm that grazers have an overall negative effect on macroalgal recruitment. If this were the case, $P$. limitata recruitment would have occurred in all plots excluding grazers regardless of the presence or absence of barnacles. It is likely that $P$. limitata spores are settling both on barnacle and bare rock, but not surviving on bare rock. The smooth surface of the Santa Cruz Mudstone may not provide the same advantages as the barnacle tests - a refuge from exposure to physical factors or the optimal substrate for algal spore attachment.

Further examination of limpet densities at Waddell Creek show that limpets were most abundant in plots where barnacles were present (Figure 12). Limpet densities nearly crashed in plots immediately following the removal of barnacles for experimental manipulation (Figure 12). This suggests that there was a positive interaction occurring between $B$. glandula and limpet grazers, an observation that again challenges the current paradigm that $B$. glandula has a negative effect on limpet grazers by altering the substrate and making it difficult to graze. In examining the limpet species data (Table 10), L. paradigitalis and L. digitalis/austrodigitalis were the most common species present at Waddell Creek. These species were often observed associating with B. glandula in plots where barnacles were present, and were either directly on the barnacle tests, or attached to substrate close to the bases of barnacle tests. Perhaps the barnacles provide a refuge to 
the limpets during low tide, sheltering them from desiccation stress and extreme temperature shifts. A few studies showed that vertical surfaces are actually cooler than horizontal surfaces in the intertidal zone, and that limpets attached to vertical surfaces during low tide were less likely to experience heat-related mortality (Miller, Harley, \& Denny, 2009; Williams \& Morritt, 1995). Attaching to the vertical side of a barnacle test may help regulate limpet body temperature and keep the organism cooler during low tide than attaching to the horizontal surface of the bare rock.

On a smooth substrate, like the Santa Cruz Mudstone at Waddell Creek, the barnacles also provide a more complex habitat structure and increased surface area, thereby creating more space for occupation by other organisms such as macroalgae and limpets (Creese, 1982). In environments such as the rocky intertidal where space is a limiting factor, increasing the available space for occupation by organisms could play an important role in structuring the community, especially when the underlying rock lacks surface complexity.

Similar studies inspired by Dayton's (1971) work on rocky intertidal community structure conducted primarily on smooth substrates like the mudstone at Waddell Creek, almost always concluded that grazers directly, negatively impacted macroalgal colonization in the rocky intertidal and that barnacles had a negative impact on grazer activity (Anderson, 1999; Brock et al., 2007; A. R. O. Chapman, 1989, 1990; Dayton, 1971; M.N. Dethier \& Duggins, 1984; Megan N. Dethier et al., 2005; Duffy \& Hay, 1990; Dungan, 1986; Geller, 1991; Jernakoff, 1983, 1985; Kim, 1997; Lubchenco, 1983). Each study that experimentally manipulated the presence and absence of grazers in 
treatment plots observed macroalgal recruitment in plots that excluded grazers, both on bare rock or other organisms such as barnacle tests. At Waddell Creek, conclusions painted an alternate picture, and eliminated interactions as well as added a novel interaction (Figure 16b) between these organisms to the previously established interaction web (Figure 16a). P. limitata recruitment almost never occurred on bare rock even when grazers were excluded, and recruitment occurred in all treatments that included barnacles even when grazers were present. Limpet grazers had little to no effect, neither negative nor positive, on macroalgal recruitment in the high intertidal zone at Waddell Creek, and B. glandula did not appear to be negatively affecting the grazing activity of the limpets, as limpet densities were highest in treatments that included barnacles. Because limpets had no effect on P. limitata recruitment at Waddell Creek, the role of the barnacle as a grazer refuge became obsolete, thereby eliminating the indirect, positive interaction between the alga and the barnacle. The refuge from physical factors and optimal attachment substrate provided by the increase in surface heterogeneity created by the barnacle tests is the likely driver of the interaction between $B$. glandula and P. limitata. The interactions between $B$. glandula and limpet grazers in turn shift, as the negative interaction between these species in treatments where both these organisms were present is eliminated and actually turns positive. Again, the increased surface complexity provided by the barnacle tests is likely creating refuge from physical factors for the limpet grazers. The barnacle-fucoid-grazer interaction web at Waddell Creek is shaped by the presence of the barnacle because of the habitat the barnacle tests provides that the smooth mudstone does not, which presents a question: What would happen to this 
interaction web if an increase of small-scale heterogeneity and complexity of the underlying rock surface provided similar habitat structure as the barnacle tests?

To examine the potential effects of the variation in substrate type and geographic location on this species interaction web, the experiment was replicated at Soberanes Point. The intertidal bench at this site is composed of granodiorite, an igneous rock boasting more small-scale surface complexity $(\mathrm{cm}-\mathrm{mm})$ than the mudstone that occurs at Waddell Creek. Testing the effects of experimental manipulations of the presence and absence of barnacles and limpet grazers on P. limitata recruitment helped shape a species interaction web specific to Soberanes Point (Figure 16c), which looks much different than the web occurring at Waddell Creek, and again challenges the established paradigms for this interaction web. Results of a one-way ANOVA testing the main effects of experimental manipulations on P. limitata recruitment were significant (Figure 10), and multiple comparisons showed significant differences between treatment 1 (+barnacles, +grazers) and treatments 2 (+barnacles, -grazers) and 4 (-barnacles, -grazers) (Table 7). Observations showed that the highest recruitment almost always occurred in plots where grazers were present (Figure 9), regardless of the presence or absence of barnacles, which suggests a positive interaction exists between grazers and $P$. limitata recruits. Barnacles don't appear to have an effect, which eliminated the direct and indirect, positive interactions between the barnacle and the alga. Whether the interaction between grazers and $P$. limitata recruits is direct or indirect cannot be definitively determined, although certain observations suggest that this interaction is indirect. Past studies showed that invertebrate grazers may have an indirect, positive effect on macroalgal colonization in 
certain zones of the intertidal, particularly at sites that experience development of microfilm on the rock surface, usually caused by the deposition of diatoms during increased upwelling events (Bruce Menge \& Menge, 2013). Limpets graze these microfilms, which could free up space for macroalgal spores to settle and develop (Connell, 1972; Bruce Menge, 2000; Sousa, 1979). Diatom microfilm was often observed building up in grazer exclusion treatments at Soberanes Point over the length of the experiment. This microfilm could have had a deleterious effect on $P$. limitata recruitment in these plots. In areas surrounding these treatments, where limpets were present and freely grazing, the rock was clear of diatom microfilm, and P. limitata recruits were often observed. Previous experiments conducted just up coast at this site showed a decrease in P. limitata recruitment in areas where microfilm and ephemeral macroalgae were allowed to colonize space (Szoboszlai, 2008). In many rocky intertidal habitats when space is freed up by a disturbance, successional stages follow an established pattern (Connell \& Slatyer, 1977; Dayton, 1971; Murray \& Littler, 1978; Sousa, 1979). Generally, ephemeral micro and macro algae settle in newly freed space first, and grazers clear this algae freeing up space for the establishment of perennial algae such as $P$. limitata. By excluding grazers at Soberanes Point, the successional step after the settlement of ephemeral algae did not occur, thereby halting succession and the establishment of perennial algae. Diatom microfilm was not observed accumulating at Waddell Creek; so excluding grazers did not produce this effect.

Recruitment in treatment 5 (artifact control) at Soberanes Point was significantly lower than treatment 1 (+barnacles, + grazers), which suggests that the copper fences had 
an effect on P. limitata recruitment. However, the artifact control did not have an effect on P. limitata recruitment at Waddell Creek. In fact, the two plots that experienced the highest recruitment, so high they couldn't be accurately counted, were both artifact controls, so it is unlikely that the copper fences were directly affecting recruitment at Soberanes Point, and other underlying factors induced by the presence of the copper fences are likely to blame for the results. As water was often seen collecting in the treatments with enclosed copper fences at Soberanes Point, the potential effect of increased humidity on P. limitata recruitment was addressed. Submersion in water has been shown to cause increased mortality of $P$. limitata spores and other high intertidal algae (A.R.O Chapman, 1995; Rugg \& Norton, 1987). Humidity measurements between treatments and between sites were compared and showed no effect, so the potential influence of increased humidity in the grazer exclusion plots on $P$. limitata recruitment was ruled out.

In examining the limpet density data at Soberanes Point, there were fewer limpets over time in the treatment control plots than the plots that didn't have fences, suggesting that just the presence of the copper deterred some grazers from entering artifact control plots, thereby driving limpet densities down in these plots. Because previous studies on succession and the results of this study suggested that presence of limpets might indirectly benefit $P$. limitata recruitment after a disturbance (Connell \& Slatyer, 1977; Murray \& Littler, 1978), the copper could have had a negative, indirect effect on $P$. limitata recruitment by deterring grazers. Limpet densities in artifact controls at Waddell Creek were similarly low, but because limpets didn't appear to have any effect on $P$. 
limitata recruitment at that site, there was not a significant difference between the artifact control and other treatments. Although the effects of the copper fences couldn't be definitively separated from actual effects, observations suggests that the copper fences were not the main cause behind the observed results, and conclusions about species interactions at Soberanes Point can still be reached.

In comparing the interaction web from Waddell Creek to Soberanes Point, it is clear that the interactions between these species differed geographically. Neither interaction web adheres to the published interaction paradigm (Anderson, 1999; Brock et al., 2007; A. R. O. Chapman, 1989, 1990; Dayton, 1971; M.N. Dethier \& Duggins, 1984; Megan N. Dethier et al., 2005; Duffy \& Hay, 1990; Dungan, 1986; Geller, 1991; Jernakoff, 1983, 1985; Kim, 1997; Lubchenco, 1983) between these species (Figure 16). New interactions were established, and previously described interactions were eliminated from the paradigm of the barnacle-fucoid-grazer interaction web in both site-specific webs (Figure 16b,c). Results of this study are surprising given that previous studies often occurred in vastly different geographic regions, but came to the same conclusions about similar species assemblages. Observations stress the importance of determining interaction webs involving the same set of species at any given site before proceeding to the examination of the potential physical and biological drivers of these interactions.

The substrate type is one of the primary differences in physical factors between Waddell Creek and Soberanes Point that could be contributing to the variation in interactions between these species. The small-scale surface complexity of the underlying rock at each site on an mm-cm scale is visibly different (personal observation, 2012). 
Observations depicted in Figures 8 and 11 show that $P$. limitata recruits are utilizing the available settlement substrates, primarily bare rock and barnacles, differently between sites. At Waddell Creek, recruits were almost exclusively observed settled on barnacle tests, despite the sufficient space on bare rock available. Statistical tests confirmed a significant difference between $P$. limitata recruitment on barnacles versus rock. At Soberanes Point, $P$. limitata recruits were observed on both barnacles and rock, and more commonly settled directly on rock even though space on barnacles was available. Statistical tests showed no difference in P. limitata recruitment between substrates, suggesting that barnacle tests and bare rock provide a similar habitat for macroalgal recruits. One of the physical features of granodiorite, the most common rock type at Soberanes Point, is embedded crystals, usually composed of feldspar (Howard, 1979). These crystals are often a similar size and sometimes shape as that of the barnacle $B$. glandula (personal observation 2012) and could be providing a similar settlement habitat as the barnacle test for macroalgal recruits. Benefits of a more rugose settlement habitat provided by either the rock surface or barnacle tests could provide protection from wave force or desiccation (Kim, 1997; Lubchenco, 1983), among other physical stressors. Interactions between barnacles and macroalgae would thereby be stronger at sites like Waddell Creek where the rock type provides little to no habitat complexity on the mm$\mathrm{cm}$ scale, and less important at sites like Soberanes Point where the actual rock essentially plays the role of the barnacle in the interaction web.

Variation in rock type could also be influencing the differences in interactions between limpet grazers and $P$. limitata recruits between sites. The most obvious 
difference in limpet population structure at both sites was overall limpet abundance (Table 9). Limpets were much more abundant at Soberanes Point. Although experimental plots were the same circumference at both sites, the actual 3-D surface area is potentially higher at Soberanes Point than at Waddell Creek because of the increased surface complexity of the rock. A few studies have shown that the surface area of rock types with increased surface complexity is greater than rock types with a less complex surface (Barrett, 2006; Fischer \& Reinhard, 2004). More surface area means more overall space for occupation by intertidal organisms such as limpets, thereby increasing the abundance of organisms in any given area (Beck, 2000; Kostelyv, Erlandsson, Ming, $\&$ Williams, 2005). This increase in surface area of the underlying substrate could play an important role in structuring communities like the rocky intertidal where space is one of the main limiting factors.

Small-scale surface complexity may also be one of the factors structuring differences between limpet species abundances amongst sites. Limpet radula morphology is often used to distinguish and identify species (Lindberg, 1981). Shape and dimension can vary greatly, even between closely related species of limpets (Lindberg, 1981). Past studies, primarily conducted on freshwater limpets, note that differences in radula morphology may drive resource partitioning in different species occupying the same space (Blinn, Truitt, \& Pickert, 1989; Hawkins et al., 1989). A recent study conducted in the Monterey Bay area on limpets in the high rocky intertidal focused on how radula morphology affects resource partitioning between species occupying the same zone, and suggests that small-scale surface complexity and substrate 
hardness may be a factor in grazing behavior of invertebrate grazers (LaScalaGruenewald, in prep). Past research has shown that less force is required to remove microalgae from harder surfaces, so perhaps limpets graze more efficiently on harder substrates (Padilla, 1985), such as the granodiorite at Soberanes Point.

\section{Conclusion}

Species interactions and the abiotic factors that affect them play an important role in structuring communities (Connell, 1972; Dayton, 1971; Harley, 2008; Harley \& Helmuth, 2003). The novel results presented in this study stress the importance of defining interaction webs before making conclusions on how physical factors influence web structure. Results demonstrate that the same species interact with each other in dissimilar capacities across intertidal sites, and further exploration of the factors driving these differences is required. Pelvetiopsis limitata colonization in the high intertidal appears to be dependent on different factors at both sites, which implies that recovery and succession, and shifts in community structure in the high intertidal could be occurring at different rates and through dissimilar processes at each site. At Waddell Creek, the presence of barnacles appears to be driving $P$. limitata recruitment, while high densities of limpet grazers positively affect recruitment at Soberanes Point.

One of the glaring differences in physical factors between these sites is substrate type. This is common throughout California, and rock type can change over very small distances. Results showed that the targeted species, primarily P. limitata and limpet grazers, were utilizing the substrate differently at both sites, which could help explain the 
contrasting interaction webs. Quantitatively defining small-scale complexity of the rock types composing intertidal systems along the California coast is an essential next step in scientifically linking substrate type to intertidal community structure.

Often, interaction webs are built on the assumption that if species co-exist in an ecosystem, interactions, either direct or indirect, between these species are assumed to occur simply because they share space. Results of this study suggest that co-existing species may not always interact, especially at certain life-history stages (i.e. recruitment stage of $P$. limitata), which is surprising given that both the presence or absence of barnacles and grazers in this system are thought to drive the distribution of macroalgae in the high intertidal zone. Eliminating one organism at any given site could have very different effects than eliminating the same organism at another site, an important factor to consider when addressing community response to a changing environment across broad geographical ranges. 


\section{Literature Cited}

Anderson, M. J. (1999). Distinguishing direct from indirect effects of grazers in intertidal estuarine assemblages. Journal of Experimental Marine Biology and Ecology, 234, 199-218.

Barrett, P. (2006). The shape of rock particles, a critical review. Sedimentology, 27, 291303.

Beck, M. (2000). Separating the Elements of Habitat Structure: Independent Effects of Habitat Complexity and Structural Components on Rocky Intertidal Gastropods. Journal of Experimental Marine Biology and Ecology, 249, 29-49.

Bergeron, P., \& Bourget, E. (1986). Shore topography and spatial partitioning of crevice refuges by sessile epibenthos in an ice disturbed environment. Mar. Ecol. Prog. Ser, 28, 129-145.

Bertness, M. D., \& Callaway, R. (1994). Positive interactions in communities. Trends in Ecology \& Evolution, 9, 191-193.

Blinn, D., Truitt, R., \& Pickert, A. (1989). Feeding Ecology and Radular Morphology of the Freshwater Limpet Farissia fragilis. Journal of the North American Benthological Society, 8, 237-232.

Brock, E., Nylund, G. M., \& Pavia, H. (2007). Chemical inhibition of barnacle larval settlement by the brown alga Fucus vesiculosus. Marine Ecology Progress Series, $337,165-174$.

Bruno, J. F., Stachowicz, J. J., \& Bertness, M. D. (2003). Inclusion of facilitation into ecological theory. Trends in Ecology \& Evolution, 18(3), 119-125.

Bulleri, F. (2009). Facilitation research in marine systems: state of the art, emerging patterns and insights for future developments. Journal of Ecology, 97, 1121-1130.

Carlson, R. L., Shulman, M. J., \& Ellis, J. C. (2006). Factors contributing to spatial heterogeneity in the abundance of the common periwinkle Littorina littorea (L.). Journal of Molluscan Studies, 72, 149-156.

Chapman, A. R. O. (1989). Abundance of Fucus spiralis and ephemeral seaweeds in a high eulittoral zone: effects of grazers, canopy and substratum type. Marine Biology, 102, 565-572. 
Chapman, A. R. O. (1990). Effects of Grazing, Canopy Cover and Substratum Type on the Abundances of Common Species of Seaweeds Inhabiting Littoral Fringe Tide Pools Botanica Marina (Vol. 33, pp. 319).

Chapman, A. R. O. (1995). Functional ecology of fucoid algae: twenty-three years of progress. Phycologia, 34, 1-32.

Chapperon, C., \& Seuront, L. (2011). Space-time variability in environmental thermal properties and snail thermoregulatory behaviour. Functional Ecology, 25, 10401050.

Charters, A. C., Neushul, M., \& Coon, D. (1973). The Effect of Water Motion on Algal Spore Adhesion. Limnology and Oceanography, 18, 884-896.

Connell, J. H. (1972). Community interactions on marine rocky intertidal shores. Annual Review of Ecology and Systematics, 3, 169-192.

Connell, J. H., \& Slatyer, R. O. (1977). Mechanisms of Succession in Natural Communities and Their Role in Community Stability and Organization. The American Naturalist, 111, 1119-1144.

Coombes, M. A., \& Naylor, L. A. (2012). Rock warming and drying under simulated intertidal conditions, part II: weathering and biological influences on evaporative cooling and near-surface micro-climatic conditions as an example of biogeomorphic ecosystem engineering. Earth Surface Processes and Landforms, 37, 100-108.

Creese, R. G. (1982). Distribution and Abundance of the Acmaeid Limpet, Patteloida latistrigata, and its Interaction with Barnacles. Oecologia, 52, 85-96.

Dayton, P. K. (1971). Competition, Disturbance, and Community Organization: The Provision and Subsequent Utilization of Space in a Rocky Intertidal Community. Ecological Monographs, 41, 351-389.

Denny, M. (1995). Predicting physical disturbance - mechanistic approaches to the study of surviviorship on wave-swept shores. Ecological Monographs, 65, 371-418.

Dethier, M. N., \& Duggins, D. O. (1984). An "indirect commensalism" between marine herbivores and the importance of competitive hierarchies. American Naturalist, 124, 205-219.

Dethier, M. N., Williams, S. L., \& Freeman, A. (2005). Seaweeds under stress: manipulated stress and herbivory affect critical life-history functions. Ecological Monographs, 75, 403-418. 
Duffy, J. E., \& Hay, M. E. (1990). Seaweed adaptations to herbivory. Bioscience, 40, 368-375.

Dungan, M. L. (1986). Three-Way Interactions: Barnacles, Limpets, and Algae in a Sonoran Desert Rocky Intertidal Zone. The American Naturalist, 127, 292-316.

Espinosa, F., Rivera-Ingraham, G., \& Garcia-Gomez, J. C. (2011). Influence of habitat structure and nature of substratum on limpet recruitment: Conservation implications for endangered species. Estuarine Coastal and Shelf Science, 94, $164-171$.

Farrell, T. M. (1991). Models and mechanisms of succession: An example from a rocky intertidal community. Ecological Monographs, 61(1), 95-113.

Fischer, C., \& Reinhard, G. (2004). Multi-scale rock surface area quantification-a systematic method to evaluate the reactive surface area of rocks. Geochemistry, 64, 241-256.

Friedland, M. T., \& Denny, M. W. (1995). Surviving hydrodynamic forces in a wave swept environment: consequences of morphology in the feather boa kelp, Egregia menzenseii (Turner). Journal of Experimental Marine Biology and Ecology, 190, 109-133.

Gaines, S., Brown, S., \& Roughgarden, J. (1985). Spatial variation in larval concentrationa as a cause of spatial variation in settlement for the barnacle, Balanus glandula. Oecologia, 67, 267-272.

Gedan, K. B., Bernhardt, J., Bertness, M. D., \& Leslie, H. M. (2011). Substrate size mediates thermal stress in the rocky intertidal. Ecology, 92, 576-582.

Geller, J. (1991). Gastropod grazers and algal colonization on a rocky shore in northern California: the importance of the body size of grazers. Journal of Experimental Marine Biology and Ecology, 150, 1-17.

Hacker, S. D., \& Gaines, S. D. (1997). Some implications of direct, positive interactions for community species diversity. Ecology, 78, 1990-2003.

Harley, C. D. G. (2008). Tidal dynamics, topographic orientation, and temperaturemediated mass mortalities on rocky shores. Marine Ecology Progress Series, 371, $37-46$.

Harley, C. D. G., \& Helmuth, B. S. T. (2003). Local and regional scale effects of wave exposure, thermal stress, and absolute versus effective shore level on patterns of intertidal zonation. Limnology and Oceanography, 48, 1498-1508. 
Hawkins, S., Watson, D., Hill, A., Harding, S., Kyriakides, M., Hutchinson, S., \& Norton, T. (1989). A Comparison of Feeding Mechanisms in Microphagous, Herbivorous, Intertidal, Prosobranchs in Relation to Resource Partitioning. Journal of Molluscan Studies, 55, 151-165.

Hayes, M., \& Michel, J. (Eds.). (2010). A Coast to Explore: Coastal Geology and Ecology of California: Pandion Books.

Helmuth, B., \& Denny, M. W. (2003). Predicting wave exposure in the rocky intertidal zone: Do bigger waves always lead to larger forces-9. Limnology and Oceanography, 48, 1338-1345.

Howard, A. (Ed.) (1979). Geological History of Middle California: University of California Press.

Jernakoff, P. (1983). Factors affecting the recruitment of algae in a midshore region dominated by barnacles. Journal of Experimental Marine Biology and Ecology, 67, 17-31.

Jernakoff, P. (1985). An experimental evaluation of the influence of barnacles, crevices and seasonal patterns of grazing on algal diversity and cover in an intertidal barnacle zone. Journal of Experimental Marine Biology and Ecology, 88, 287302.

Kim, J. H. (1997). The role of herbivory, and direct and indirect interactions, in algal succession. Journal of Experimental Marine Biology and Ecology, 217, 119-135.

Kordas, R. L., Harley, C. D. G., \& O'Connor, M. I. (2011). Community ecology in a warming world: The influence of temperature on interspecific interactions in marine systems. Journal of Experimental Marine Biology and Ecology, 400, 218226.

Kostelyv, V., Erlandsson, J., Ming, M. Y., \& Williams, G. (2005). The Relative Importance of Habitat Complexity and Surface Area in Assessing Biodiversity: Fractal Application on Rocky Shores. Ecological Complexity, 2, 272-286.

Lindberg, D. (1981). Acmaeidae:Gastropoda Mollusca: Boxwood Press.

Lubchenco, J. (1983). Littornia and fucus: effects of herbivores, substratum heterogeneity, and plant escapes during succession. Ecology, 64, 1116-1123.

Maggi, E., Bertocci, I., Vaselli, S., \& Benedetti-Cecchi, L. (2011). Connell and Slatyer's models of succession in the biodiversity era. Ecology, 92, 1399-1406.

Magurran, A. (1988). Ecological Diversity and its Measure: Princeton University Press. 
McQuaid, C., \& Branch, G. (1984). Influence of sea temperature, substratum and wave exposure on rocky intertidal communities: An analysis of faunal and floral biomass. Marine ecology progress series. Oldendorf, 19, 145-151.

Menge, B. (1997). Detection of Direct versus Indirect Effects: Were Experiments Long Enough? The American Naturalist, 149, 801-823.

Menge, B. (2000). Top-Down and Bottom-Up Community Regulation in Marine Rocky Intertidal Habitats. Journal of Experimental Marine Biology and Ecology, 250, 257-282.

Menge, B., \& Menge, D. (2013). Dynamics of Coastal Meta-Ecosystems:The Intermittent Upwelling Hypothesis and a Test in Rocky Intertidal Regions. Ecological Monographs, 83, 283-310.

Miller, L., Harley, C., \& Denny, M. (2009). The role of temperature and desiccation stress in limiting the local-scale distribution of the owl limpet, Lottia gigantea. Functional Ecology, 23, 756-767.

Murray, S., \& Littler, M. (1978). Patterns of algal succession in a perturbated marine intertidal community. Journal of Phycology, 14, 506-512.

Nicotri, M. E. (1977). Grazing Effects of Four Marine Intertidal Herbivores on the Microflora. Ecology, 58, 1020-1032.

O'Donnell, M. J., \& Denny, M. W. (2008). Hydrodynamic forces and surface topography: Centimeter-scale spatial variation in wave forces. Limnology and Oceanography, $53,579-588$.

Padilla, D. (1985). Structural resistance of algae to herbivores. Marine Biology, 90, 103109.

Paine, R. T. (1977). Controlled Manipulations in the Marine Intertidal Zone, and Their Contributions to Marine Ecological Theory. In C. E. Goulden (Ed.), Changing Scenes in the Natural Sciences, 1776-1976: : Academy of Natural Sciences.

Paine, R. T., \& Simon, A. L. (1981). Intertidal Landscapes: Disturbance and the Dynamics of Pattern. Ecological Monographs, 51, 145-178.

Raimondi, P. T. (1988). Rock type affects settlement, recruitment, and zonation of the barnacle Chthamalus anisopoma Pilsbury. Journal of Experimental Marine Biology and Ecology, 123, 253-267.

Robles, C., \& Desharnais, R. (2002). History and current development of a paradigm of predation in rocky intertidal communities. Ecology, 83, 1521-1536. 
Robles, C. D., Desharnais, R. A., Garza, C., Donahue, M. J., \& Martinez, C. A. (2009). Complex equilibria in the maintenance of boundaries: experiments with mussel beds. Ecology, 90, 985-995.

Robles, C. D., Garza, C., Desharnais, R. A., \& Donahue, M. J. (2010). Landscape patterns in boundary intensity: a case study of mussel beds. Landscape Ecology, $25,745-759$.

Rugg, D. A., \& Norton, T. A. (1987). Pelvetia canaliculata, a seaweed that shuns the sea. In R. M. M. Crawford (Ed.), Plant Life in Aquatic and Amphibious Environments (pp. 347-358): Blacwells, Oxford.

Sousa, W. (1979). Experimental Investigations of Disturbance and Ecological Succession in a Rocky Intertidal Algal Community. Ecological Monographs, 49, 227-254.

Stachowicz, J. (2001). Mutualism, Facilitation, and the Structure of Ecological Communities. BioScience, 51, 235-246.

Szoboszlai, A. (2008). Positive and Negative Effects of Intertidal Algal Canopies on Fucoid Recruitment., Moss Landing Marine Laboratories Masters Thesis, San Jose State University.

Wheeler, A. (2015). Predicting multi-scale geomorphological expressions of rocky intertidal outcrops along the California coast. Moss Landing Marine Laboratories Masters Thesis, San Francisco State University.

Williams, G., \& Morritt, D. (1995). Habitat partitioning and thermal tolerance in a tropical limpet, Cellena grata. Marine Ecological Progress Series, 124, 89-103.

Wootton, J. T. (1993). Indirect Effects and Habitat Use in an Intertidal Community: Interaction Chains and Interaction Modifications. The American Naturalist, 141, 71-89.

Wootton, J. T. (1994). The Nature and Consequences of Indirect Effects in Ecological Communities. Annual Review of Ecology and Systematics, 25, 443-466.

Wootton, J. T. (2002). Indirect effects in complex ecosystems: recent progress and future challenges. Journal of Sea Research, 48, 157-172.

Zar, J. (1984). Biostatistical Analysis (2nd ed.): Prentice-Hall. 